\title{
Att rädda planeten genom konsumtionsval Oatlys antagonistiska och lekfulla marknads- kommunikation
}

\author{
Av PER LEDIN \& DAVID MACHIN
}

\begin{abstract}
Ledin, Per, per.ledin@sh.se, Professor, School of Culture and Education, Södertörn University; Machin, David, david.machin@oru.se, Professor, School of Humanities, Education and Social Sciences, Örebro University: "Saving the planet through acts of consumption. Oatly's antagonistic and playful marketing communication”. Språk och stil NF 29, 2019, pp. 99-133.

There has been an increase in food products marketed through buzzwords like 'organic', 'local', 'recyclable', 'Fairtrade'. These have been described as part of a newer kind of ethical or emotional capitalism, where consumers can align with political issues through shopping. In this paper, we look at the brand Oatly, a Swedish milk alternative that has had global success. Oatly brands itself as sustainable and offers us the chance to save the planet by buying their oat milk. We carry out a critical multimodal discourse analysis of their value-based marketing communication. The results show that Oatly mixes the antagonistic and the playful and utilizes various semiotic materials in refined ways. We find signifiers of clear and direct political action from former times, for example in film clips and packaging design. The playful runs through many poster campaigns with posters that refer to each other, where we engage in a kind of hide and seek. The meta-communication that arises when Oatly says it is not advertising presents the company as an underdog going against the milk industry. Overall, this is a form of activism which is fun, chic and rather easy. Our critique of this kind of marketing communication is that acts of consumption shape what we know about, and how we act towards, actual socio-political matters. If global large companies are to control our money and feelings and decide how environmental problems are defined, we might not be able to save the planet.
\end{abstract}

Keywords: ethical food, Swedish marketing communication, multimodal critical discourse analysis, consumerism, politics, language play, meta-communication, packaging.

Vi lever i en tid där jorden är hotad och där ordet hållbarhet återkommer i alla möjliga sammanhang. Lindsey (2011) pekar till exempel på begrepp som »sustainable economic development», »sustainable knowledge», »sustainable businesses» och »sustainable democracy». På svensk botten kan vi notera att regeringen 2016 lanserade en strategi för hållbar konsumtion i ett miljömässigt, socialt och ekonomiskt perspektiv (Regeringskansliet 2016). Också som individer ska vi vara hållbara. En bok typisk för vår tid är Handbok för en hållbar människa: ta hand om dig och planeten samtidigt (Rolfsdotter-Jansson 2018). 
Det finns kritik av denna hållbarhetsdiskurs. Det har hävdats att hållbarhet $\mathrm{i}$ värsta fall används som en gröntvättning där företag och organisationer vill skapa lönsamma associationer till sitt varumärke snarare än ta sig an faktiska miljöproblem (Atkinson \& Kim 2015). Cook (2011) talar i detta sammanhang om »green capitalism» och ser en sådan kapitalism som en fiktion. Kapitalism innefattar ackumulering och expansion, att marknadsandelar ökar och vinster växer, vilket med nödvändighet är miljöbelastande. Ur ett marknadsföringsperspektiv är det ändå självklart att vara grön för att kunna bli framgångsrik. Till exempel Otman (2011) ställer upp 20 regler för grön marknadsföring. Dit hör att grönt i dag är självklart för de flesta, att det är coolt, att hållbarhet ska vara en del av själva produkten och att varumärken måste ta socialt ansvar.

Varumärken marknadsförs alltså i dag på gröna och etiska grunder, som något bra för vår hälsa, jord och miljö. Vi möter ord som organisk, ekologisk, närodlad, lokalproducerad, bra miljöval, GMO-fri, Fairtrade, som innebär rättvisemärkning, vilket inte är detsamma som KRAV-märkt eller Svanen-märkt osv. Vad orden mer exakt betecknar kan vara svårt att veta, som vad som gör det ekologiskt märkta kaffet, ofta importerat från Sydamerika, miljövänligt. Man inser därtill lätt att ett lokalproducerat vin inte behöver vara särskilt ekologiskt utan mycket väl kan framställas med hjälp av kemikalier och bekämpningsmedel. Ändå försöker många att handla på ett miljövänligt sätt och köpa det som framställs som hållbart. I det ligger att vår konsumtion, inte minst av mat, har blivit allt mer moralisk, så att vi genom matinköp kan ta ställning för det goda och rätta.

I den här artikeln tar vi oss an matvarumärket Oatly och deras havreprodukter. Vi gör en fallstudie av deras marknadskommunikation, som handlar om att rädda planeten. Oatly har framgångsrikt framställt sig som underdogen som går emot storföretagen och kämpar för jordens överlevnad. Som konsumenter bjuds vi in att ansluta oss till Oatlys kamp genom att köpa rätt och välja havredryck i stället för mjölk.

\section{Syfte}

Artikeln syftar till att kritiskt belysa Oatlys marknadskommunikation. Vi gör en socialsemiotisk analys och visar hur Oatly har skapat en antagonistisk retorik, där först mjölkindustrin och sedermera hela livsmedelsindustrin är fienden. Marknadskommunikationen innefattar ett särskilt tilltal, som är hu- 


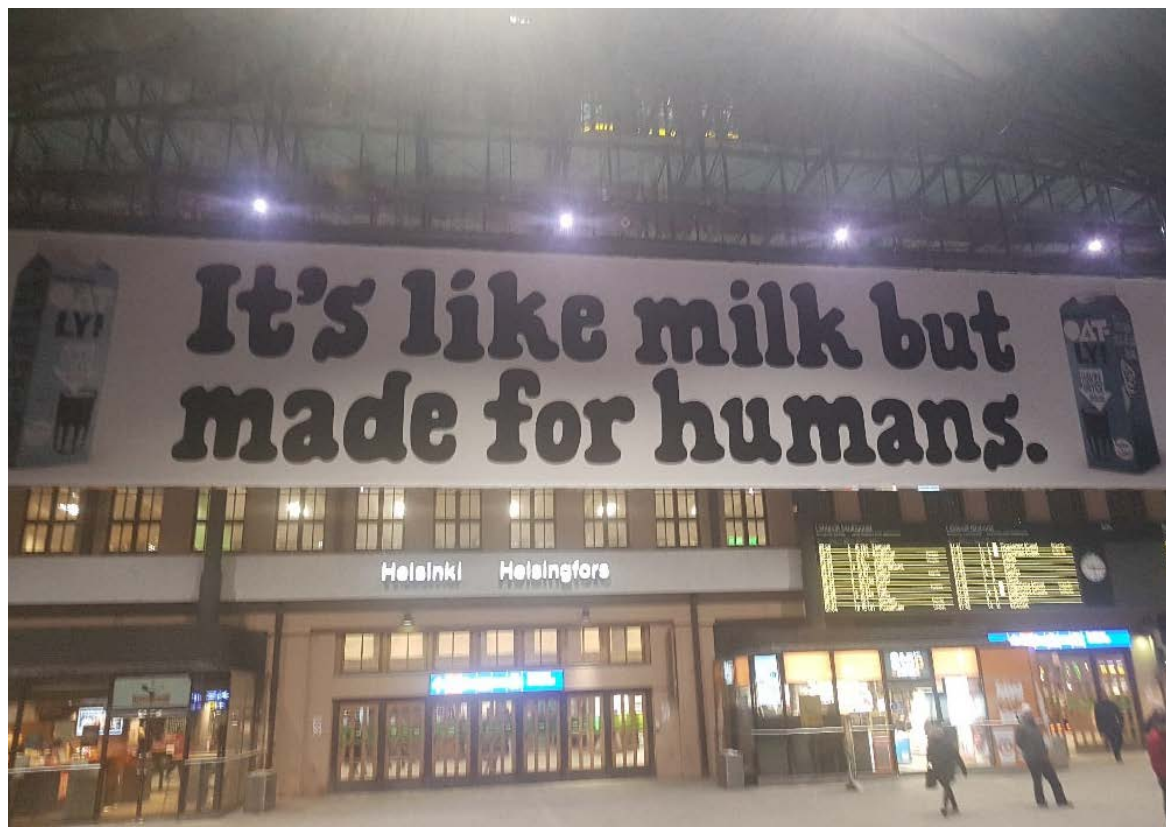

Figur 1. Oatly-banderoll från Helsingfors centralstation, mars 2019 (författarfoto).

moristiskt och lekfullt. Det offentliga rummet görs om till ett politiskt och varumärkt rum där du som konsument förväntas ta ställning för det goda. Denna kommunikation har gett Oatly globala marknadsframgångar under 2010-talet.

Figur 1 exemplifierar Oatlys antagonistiska och lekfulla retorik. Det vi ser är en banderoll med Oatlys taktfasta huvudslogan »It's like milk but made for humans». Den fanns uppsatt på Helsingfors centralstation i mars 2019, och med sin storlek dominerade den stationshallen. På en offentlig och välbesökt plats iscensätter den debatt och polemiserar mot mejerinäringen.

Vår kritiska ansats har ingenting att göra med alternativa mjölkprodukter i sig. Att människor föredrar drycker gjorda av havre, soja, kokos, mandel osv. har vi ingenting emot, lika lite som vi har något emot ekologisk mat i sig. Mjölk- och köttproduktion är en av många komplexa miljöfrågor att diskutera. Den sociala förändring vi vill diskutera rör att politik i dag är kopplat till globala företag och de produkter och värden som de marknadsför. Politik blir då en fråga om individuella konsumtionsval och inte, som förr, något som hör 
hemma i den liberala demokratin. Och politik bygger på kommunikation, vare sig den bedrivs av storföretag som Oatly eller av traditionella partier.

Vi ser Oatly som en del av vad som brukar kallas en nyliberal utveckling, där statens traditionella roll mer och mer tas över av marknaden (t.ex. Beck \& Beck-Gernsheim 2002). Det blir då individens uppgift att välja och köpa rätt och på så vis bli en hållbar människa som står för en hållbar planet. Detta kräver en konsument med ekonomiska resurser och stöder, menar vi, i grunden en kapitalistisk marknadslogik (jfr Banet Weiser \& Mukherjee 2012). Ytterst blir det globala storföretag som styr vilka miljömässiga utmaningar som hamnar på agendan.

Oatly ska ses som ett exempel på denna sociala förändring, som vi menar är värd att belysas kritiskt. Vår analys tar särskilt sikte på hur Oatly har utvecklat en marknadskommunikation som är helt värderingsbaserad, som säljer just värderingar, där vi som konsumenter förväntas göra moraliska investeringar. Den tar in det faktum att Oatly är ett globalt företag, vilket språkligt innebär att både svenska och engelska används, och berör kampanjer även utanför Sveriges gränser.

\section{Oatlys historia}

Varumärket Oatly erbjuder en mängd alternativ till mjölk. Huvudprodukten är havredryck med olika fetthalter och smaker, men det finns också glassar, crème fraiche, vaniljsås, energidrycker, latte och yoghurt (»Havregurt»). Det exakta utbudet varierar mellan olika marknader, också för att mjölkkonsumtionen är olika och inbjuder till skilda alternativ. Sverige har sedan knappt 100 år en hög konsumtion av mjölk och mejeriprodukter, inte minst på grund av det arbete föreningen Mjölkpropagandan inledde på 1920-talet, vilket bidrog till att gratis mjölk och lunch infördes i skolan 1946 (Jönsson 2006). Oatly är en del av den alternativa, växtbaserade mjölkindustrin, som blivit allt större och i dag är värd 16 miljarder dollar globalt (Franklin-Wallis 2019).

Oatly har sitt ursprung vid Lunds universitet på 1980-talet (Lagnevik m.fl. 2003 s. 122 ff.), där man experimenterade med mjölkalternativ. 1990 lyckades man, efter att ha attraherat riskkapital, framställa en havredryck där en patenterad enzymblandning tillåter havre och vatten att blandas. Med hjälp av olika tillsatser fick denna mjölk en lämplig smak, konsistens och textur, som också profilerade den mot den existerande sojamjölken. Det är ett ge- 
nomgående drag hos Oatly att både vara och inte vara som mjölk. Vatten med havre är ju något annat än mjölk, men Oatly såg till att produkten blev mjölklik.

Först såldes blandningen som bantningsmedel. 1994 bildades företaget Ceba Foods som en avknoppning från Lunds universitet, och havremjölken blev då ett alternativ för laktosintoleranta. 1996 lanserades den på ICA, liksom i Nordeuropa, där varumärket blev Mill Milk. Den svenska mjölkindustrin protesterade mot beteckningen havremjölk, som ändrades till havredryck (Oatly 2009). Ceba Foods lanserade 2001 varumärket Oatly, som i dag också är företagets namn, och breddade sortimentet. Den första egna fabriken byggdes 2006 utanför Landskrona med hjälp av nya investerare. 2009 designades förpackningarna om, och Oatly framställde sig nu som det hälsosamma alternativet, med en udd mot mjölkindustrin.

När Toni Petersson 2012 blev ny VD påbörjades ännu en omprofilering av varumärket, vilken sattes i verket 2014 och som vi återkommer till i analysen (Mccrow-Young 2016). Grundidén var att göra all kommunikation värderingsbaserad. Produkterna skulle inte marknadsföras, utan de värden som företaget stod för. Marknadsföringen, inklusive förpackningsdesignen, blev antagonistisk, med mjölkindustrin som fienden. Korna är de som förstör planeten, och att köpa komjölk framställdes som förkastligt. Oatly tog rollen som förkämpen för det goda, den som tog strid för den hållbara individen och planeten.

Till de slogans som användes hörde »It's like milk but made for humans» och »No milk. No soy. No badness». Mjölkindustrin, genom organisationen LRF Mjölk, stämde Oatly för vilseledande reklam i Marknadsdomstolen. Utslaget kom 2015 och innebar att Oatly förbjöds använda dessa slogans (i Sverige, utomlands används de fortfarande) - det kunde inte bevisas att mjölk var skadligt för människan (Wisterberg 2015). Domen blev en enorm succé för Oatly, som framstod som modiga och uppkäftiga i sin kamp mot etablissemanget, och den skaffade dem en ungdomlig supporterskara, inte minst via sociala medier.

Oatlys framgång bland unga bekräftades på musikfestivalen Way Out West 2016. Oatly trädde in som huvudsponsor och festivalen blev mjölkfri (Djerf 2015). I övrigt har marknadsföringen på senare år framgångsrikt inriktats på dels att stärka ställningen på de nordeuropeiska marknader där företaget sedan länge funnits, dels att ta sig in på den amerikanska och den kinesiska marknaden. 


\section{Etisk marknadskommunikation och matkonsumtion}

Att marknadskommunikation i dag ofta är etisk i meningen att den vill framställa produkter som ekologiska och naturliga har många uppmärksammat, inte minst socialsemiotiska forskare. Vi är vana vid att bilder av naturen används retoriskt i olika slags reklam för att signalera värden som ursprungligt, idylliskt, autentiskt m.m. (Hansen 2002). I dag kommuniceras sådana värden av många semiotiska resurser och material. Exempelvis visar Burrows (2013) hur »honest branding» tar sig uttryck i förpackningsdesignen av müsli från företaget Dorsey. Här används en dov, höstlik färgskala med jordnära toner. Alla förpackningar har en luftig layout, och på framsidan finns en enkel och stiliserad teckning av en växt, tillsammans med ett fönster som gör produkten synlig här finns inget att dölja. Som Ledin \& Machin (2018 kap. 5) säger är det i dag vanligt att förpackningar kommunicerar en produkt som kommer direkt från naturen till matbordet, och som, verkar det, inte har gått igenom någon industriell produktionsprocess.

För våra syften är det intressant att Andersson (2019) tar sig an Arlas marknadsföring i en socialsemiotisk analys av deras kosläpp vid bondgårdar. Det som möter är en välordnad och mycket svensk landsbygd. Det finns plakat där vi ser glada flickor dricka mjölk. Bondgårdarna, där en stor och uppblåsbar Arla-kossa står, är faluröda och ligger i ett öppet kulturlandskap. Borden där man kan sitta med gratis mjölk och bulle är enkla med rödvitrutiga dukar, och den svenska flaggan är hissad. Andersson argumenterar för att denna diskurs ideologiskt grundar sig på att Sverige är en modern och progressiv nation, där naturen är en demokratisk och öppen plats. Mjölk blir här något som skapar hälsa och bygger framgång (jfr Jönsson 2006).

Det kan noteras att Arla, som under 2010-talet sett mjölkförsäljningen gå ner samtidigt som Oatly vunnit marknadsandelar, i sin senaste reklamfilmskampanj använder orden »brölk», »prölk», »trölk» och »sölk», med en udd mot alternativa mjölkprodukter. I olika vardagssituationer, som till frukost och efter träning, väljer en karaktär bort dessa alternativ, och sloganen »Bara mjölk smakar mjölk» upprepas (Arla 2019). Oatlys svar på kampanjen blev att ta patent på Arlas påhittade mjölkord, något som fick Arla att anlita advokater i en process som i skrivande stund inte är avslutad (Törner 2019a).

Det autentiska tar sig också andra uttryck. När Starbucks i början av 2010talet designade om sina butiker var det för att framställa sig som en del av det traditionella lokalsamhället (Aiello \& Dickinson 2014). I de semiotiska materialen ingick exempelvis långbord $\mathrm{i}$ trä gjorda $\mathrm{av}$ gamla och patinerade plankor 
från närområdet, något som signalerar proveniens och blir ett sätt att symboliskt skapa en gemensam historia med rötter i ett 1900-tal (se Ledin \& Machin 2018 s. 115 ff. för liknande iakttagelser). Som Cavanaugh \& Shankar (2014) visar är detta att kommunicera autencitet något utmärkande för den globala kapitalismen. De tar upp språkliga distinktioner som på olika sätt suggererar autencitet på globala marknader och på så vis kan motivera ett högre pris. Bland annat undersöks charkmarknaden i Bergamo, där den lokala traditionen och hantverksskickligheten gärna betonas, trots att produktionen sedan länge är industrialiserad, med ord som till exempel terra, territorio och origini.

Denna strävan att gå tillbaka till ett förflutet kallar sociologen Bauman (2017) retrotopia. I en tid där jorden och mänskligheten står inför stora problem blickar vi inte längre framåt och organiserar oss kollektivt och politiskt för att påverka vår framtid, utan ser tillbaka. Vi idealiserar det som har varit och mytologiserar det som något stabilt, äkta och pålitligt, så att det förflutna blir en kur mot dagens problem och besvär. Clegg (2018) använder retrotopia för att förstå nutida organisationer och pekar på en etisk tomhet som bland annat hänger ihop med att sociala relationer och klyftor allt mer betingas av hur vi konsumerar på olika marknader (jfr Bauman 2007).

Den etiska marknadskommunikationen har bäring på konsumtionen, där vi kan investera i moraliska värden när vi köper mat. Vår tid genomsyras, säger sociologerna Johnston \& Cairns (2012), av »eating for change». Vi gör moraliska och politiska val, men inte kollektivt inom ramen för den liberala demokratin, utan som individer utifrån vilka värden globala matföretag säljer. Här finns ett »navigating guilt», alltså att lyckas konsumera utan att känna sig skyldig. I intervjuer framkommer hur konsumenter i USA utvecklar strategier för att navigera genom det komplexa matutbudet, där flertalet produkter säljs som etiska, hållbara, ekologiska osv. Som en informant säger: »I'd have to say I'm not ethical. [laughs] You know, a chicken's a chicken [laughs]» (a.a. s. 227). Banet Weiser \& Mukherjee (2012 s. 12) talar på ett liknande sätt om en »commodity activism», som innefattar en logik där »'doing good' and being a good consumer collapse into one and the same thing». Sådana etiska konsumtionspraktiker är »designed for the wealthy», vilket redan priset på produkterna visar. Exempelvis kostar Oatlys havredryck nästan dubbelt så mycket som vanlig mjölk.

Lagnevik m.fl. (2003), som är företagsekonomer och använder Oatly som ett exempel, noterar redan i början av 2000-talet att nya varumärken eftersträvar »high-value-added-products». Vi köper inte produkten i sig, inte heller bara en livsstil, utan vi köper värderingar som är politiskt laddade och internaliserar dem - vår konsumtion låter oss delta i kampen för jordens överlevnad i Oatlys fall. 


\section{Material}

Vi har använt fokuserad etnografi (Knoblauch 2005) för att samla in material, inklusive digital etnografi. Att utgå från fältarbete och observationer på plats har varit viktigt för att ringa in hur Oatly använder det fysiska rummet och skapar en platsbunden social interaktion. Vi har under 2018 och fram till sommaren 2019 bevakat vilka kampanjer Oatly drivit, strategiskt besökt olika urbana platser och även mataffärer. Det har gett ett rikt material som innefattar foton av bland annat affischer, banderoller och klistermärken i offentliga miljöer, inte minst tunnelbana och tåg, förpackningar i affärer och i olika hem och reklammaterial (foldrar, muggar) från events. Vi har också tagit fältanteckningar. Eftersom Oatly använder kampanjer i storstäder (men aldrig mindre orter) som ett sätt att ta plats i offentligheten, ingår sådana i materialet, mer exakt kampanjer i Stockholm 2018 och 2019, Berlin 2018 och Helsingfors 2019, vilket också är i linje med Oatlys nordeuropeiska marknadsbas. Materialet från Berlin, liksom en del foton i övrigt, är hämtade från nätet, vilket också gäller materialet från den svenska kampanjen Mjölken i skolan 2017, som vi avslutningsvis tar upp. Detta materialurval gör det möjligt att ge en fyllig bild av Oatlys kommunikation, där, menar vi, observationerna når en mättnad på så vis att ytterligare data och kampanjer inte i grunden skulle förändra den bild vi ger.

För att beskriva och problematisera kommunikationen utgår vi från tre semiotiska material som är viktiga för Oatly, närmare bestämt förpackningar, affischer och reklamfilm. Dessa relateras till de nämnda kampanjerna, där vi ibland också pekar på andra material. Det gör det möjligt för oss att visa på hur semiotiskt rik men ändå systematisk Oatlys marknadsföring är, med återkommande symboler och uttryck, anpassade till olika situationer och fysiska miljöer.

\section{Teoretiska och analytiska ingångar}

Vi utgår från socialsemiotisk teori, där Hodge \& Kress (1988) bok Social Semiotics utgör en viktig grund och där språkvetare utvecklat detaljerade analyser av olika semiotiska fenomen (t.ex. van Leeuwen 2005 och Ledin \& Machin 2018 är verk i samma tradition). Hodge \& Kress (1988 s. 12) menar att den traditionella semiotiken »likes to assume that the relevant meanings are frozen and fixed in the text itself», alltså att det finns en given kod, och att ett socialsemiotiskt perspektiv på betydelse i kontext innebär ett fokus på »the 
struggles and their uncertain outcomes that must be studied at the level of social action, and their effects in the production of meaning».

En viktig utgångspunkt är att semiotiska resurser är utvecklade i och bär spår av sociopolitiska kontexter, att de är knutna till intressen hos olika aktörer. Ytterligare en viktig utgångspunkt är att semiotiska resurser har materialitet. Denna tanke utvecklar Voloshinov (1973 s. 11) i sin marxistiska semiotik och säger »consciousness itself can arise and become a viable fact only in the material embodiment of signs». Vårt individuella och kulturella medvetande existerar alltså genom tecken, i social interaktion, och tecknet är för Voloshinov till sin natur ideologiskt. Semiotiska fenomen måste ses som situerade och materialiserade. En socialsemiotisk analys tar sig an hur semiotiska material och artefakter kommunicerar olika ideal och värden och, när den, som för oss, har en kritisk inriktning, hur dessa gynnar vissa men inte andra intressen.

Den sortens kommodifierade aktivism som Oatly driver, alltså att förändra världen genom konsumtion, bygger på en antagonistisk retorik som samtidigt är lekfull och ironisk på ett sätt som reklamspråk ofta är. Med andra ord använder Oatly uttryck som vi känner igen från traditionell reklam samtidigt som det antagonistiska, att ta strid för planeten och mot storföretagen, på olika sätt finns med. För att fånga detta har vi, med hjälp av tidigare forskning och preliminära analyser, ringat in tre betydelseskapande principer, som vi menar utmärker Oatlys marknadskommunikation. Principerna är att framkalla ett förflutet, att metakommunicera och att förkroppsliga rummet. Dessa principer ligger till grund för vår analys.

Att framkalla ett förflutet. Att reklam sedan länge och på olika sätt använder och iscensätter diskurser och röster från olika sociala sammanhang vet vi (t.ex. Cook 1992 kap. 9, Korpus 2008 kap. 7). Som vi visat i avsnitt 3 är etisk marknadskommunikation gärna baserad på att frammana ett naturligt och autentiskt ursprung för produkten (t.ex. Burrows 2013, Ledin \& Machin 2018 kap. 5). Oatly använder detta reklamgrepp för att iscensätta olika förflutna företeelser, inte minst politiska proteströrelser från det sena 1900-talet. Analytiskt använder vi »proveniens» för att fånga detta. Som Kress \& van Leeuwen (2001 s. 23) säger handlar detta om hur vi importerar tecken från andra kontexter. I praktiken känner vi igen ett visst material eller tecken från viss typ av tid och sammanhang, en social grupp eller subkultur - inte nödvändigtvis så att vi exakt kan placera tecknet, men så att, med Barthes (1977) ord, konnotationer uppstår. Exempelvis kan Oatlys val av typsnitt ibland föra tankarna till serie- och skämttidningar från det sena 1900-talet, vilket underbygger det lekfulla i kommunikationen. 
Att metakommunicera. Oatly tar gärna rollen som en uppkäftig outsider och gör det genom att på olika sätt metakommunicera, alltså genom kommunikation som riktar uppmärksamheten mot kommunikationen, inklusive språk som riktar uppmärksamheten mot språket. I vår analys fokuserar vi på tre sorters metakommunikation. Den första är språklekar, vanliga just i rubriker och slogans, och traditionellt viktiga i reklam för att skapa ett lekfullt och humoristiskt tilltal (t.ex. Myers 1994 kap. 5, Korpus 2008 kap. 6). Den andra kallar vi motstridiga förväntningar, och här riktar vi in oss på negationer och adversativa markörer, som båda är viktiga för att iscensätta motsättningar och även typiska för politisk debatt (jfr Ledin 1994). Negationer presupponerar att en motsatt eller åtminstone annorlunda värld existerar (jfr Fairclough 1992 s. 120 f.). I Oatlys slogan no badness gör negationen att en värld med badness förutsätts existera, och vi ska förstå att den har att göra med mejerinäringen. För adversativa markörer siktar vi in oss på konjunktionen men när den betyder att en förväntan motsägs och ett undantag pekas ut. I Lakoff (1971 s. 67) ges det klassiska exemplet John is a Republican but he is honest. Här finns en motstridig förväntan i det att sändaren implicerar att republikaner normalt är oärliga och John ett undantag. Att på detta vis aktualisera motstridiga förväntningar menar vi är grundläggande för Oatlys retorik. Den tredje sortens metakommunikation kallar vi paradoxer. Exempelvis säger Oatly ofta att deras reklam inte är reklam, vilket är en logisk motsägelse. Som Bateson (1972) förklarar tvingar paradoxer fram metakommunikativa inramningar. I det här fallet är, som vi ska visa, en rimlig inramning att Oatly gör parodi på traditionell reklam.

Att förkroppsliga rummet. Oatlys sätt att omforma platser och rum inbegriper att använda semiotiska material på sätt som direkt påverkar våra kroppar och därmed vår perception, något som sällan tas upp i den klassiska forskningen om reklamspråk, även om Jaworski \& Thurlow (2010) betonar att reklam bör förstås som en del av »semiotiska landskap». Scollon \& Scollon (2003 s. 205) kallar detta fokus på hur det fysiska rummet påverkar betydelseskapandet för »the principle of indexicality». De slår fast att alla semiotiska tecken »have as a significant part of their meaning how they are placed in the world» och att vi som sociala aktörer, situerade i tid och rum, blir en del av en platsbunden social interaktion. Detta ligger, menar vi, i linje med Spinozas (1994 s. 154) sätt att se på affekt som något som berör »affections of the body by which the body's power of acting is increased or diminished, aided or restrained, and at the same time, the ideas of these affections». Så vår perception och våra upplevelser av världen är beroende av vår kroppsliga hållning och rö- 
relse. Vi kommer i analysen att ta upp hur rumsliga relationer skapas och hur de gör att sociala aktörer binds till det fysiska och semiotiska rummet på olika sätt. Vi analyserar särskilt det tilltal som Oatly medvetet arbetar med och som berör kroppens relation till den omedelbara omgivningen. Rent språkligt är deixis, ofta kodat av pronomen och adverb, viktigt för att positionera kroppen och rikta uppmärksamheten. Liksom Scollon \& Scollon (2003 kap. 2) skiljer vi på tre typer av deixis, relaterade till rummet (den här), den sociala relationen (jag, $d u)$ och tiden $(d \stackrel{\circ}{a}, n u)$.

Vi berör som sagt olika semiotiska material och resurser. I detaljanalyserna använder vi oss av Ledin \& Machin (2018), där olika material analyseras, exempelvis förpackningar (kap. 5) och reklamfilm (kap. 7), och Ledin \& Machin (u.u. 2020), där betydelseskapande beskrivs utifrån semiotiska resurser, exempelvis färg (kap. 4) och typografi (kap. 5). Vad gäller språkliga iakttagelser analyserar vi svenskan, som Oatly använder i längre texter, utförligare än engelskan, som är språket i slogans och för roliga och coola formuleringar.

\section{Resultat}

I detta avsnitt presenterar vi våra resultat. Vi tar oss $\mathrm{i}$ tur och ordning an förpackningar, affischer och reklamfilm och relaterar dessa material till Oatlys kampanjer.

\subsection{Förpackningar och kampanjer}

I figur 2 ser vi Oatlys förpackningar efter omprofileringen 2014. För att skapa en sorts ursprung, en autencitet, är färgerna viktiga. De är gryniga, dämpade och ofta hybrida, i det här fallet blå-grå, annars orange-gul, och i övrigt används gärna grått och svart (se också figur 3 och 4), något som i sig kan föra tankarna till något naturligt och oprocessat (jfr Ledin \& Machin 2018 kap. 5, och Ledin \& Machin u.u. 2020 kap. 4). Det gryniga, ojämna intrycket förstärks av de barnsligt-naiva ikonerna (jfr Ledin \& Machin 2018 s. 106 ff. om ikonografi). Exempelvis ser dricksglaset på framsidan, med sina ojämna svarta toner, ut som om det vore handstencilerat, och det är inte olikt en barnboksillustration. Jämför vi med andra alternativa mjölkprodukter har de traditionellt klara färger, och framsidan innehåller ofta, som i Alpros fall - Oatlys amerikanska 
huvudkonkurrent - ett stiliserat foto av produkten (se kyldisken i figur 3), vilket var vad även Oatly använde före omprofileringen.

Om vi ser på typsnitt och slogans kan vi notera att varumärket skrivs med breda och ojämna blockbokstäver, återigen som något handgjort, och avslutas med ett utropstecken, vilket Oatly ofta använder: OATLY! Detta kontrasterar mot det traditionella typsnittet med tunna streck som hälsoprodukter brukar ha och Oatly förut hade. På sidan av förpackningen möter vi den återkommande sloganen »WOW! NO COW!» Här har vi ett rundat typsnitt. Den exakta proveniensen kan diskuteras, men att typsnittet användes på 1970-talet är säkert, till exempel i serietidningar. Det kunde också köpas på ark som s.k. gnuggisar. Sloganen är en språklek. Den är barnsligt enkel och rimmar (»wow-cow»). Den använder den för Oatly typiska negationen (»no»), som antyder en polemik mot mjölkindustrin. Det traditionella antagandet att mjölkprodukter kommer från kor gäller inte, utan här har vi alternativet, vilket emfatiskt understryks av de två utropstecknen.


Figur 2. En Oatly-förpackning efter omprofileringen 2014. 
På samma sida finns ett diagram - som återkommer i olika reklammaterial som tydligt ger uttryck för Oatlys antagonistiska retorik, återigen med barnsligt-naiva ikoner (jfr Ledin \& Machin 2018 kap. 8 om diagram). Två processer kontrasteras, produktion av komjölk och havremjölk. Kon, som äter havre, tecknas detaljerat med sina inre organ, så att en komplicerad process blir tydlig. Oatlys produktion går från de vackert stiliserade havreaxen (som också återkommer i loggan) direkt till glaset. Detta ligger i linje med vad vi tidigare iakttagit om färger och ikonografi. Oatly, vars produktion förstås är högteknologisk, framställer det som att deras havredryck kommer direkt från naturen till glaset utan att ha gått igenom någon industriell eller miljöbelastande produktionsprocess.

Det naturliga ursprunget är alltså en viktig proveniens som Oatly kommunicerar. När det gäller att frammana och iscensätta ett förflutet är det också tydligt att det sena 1900-talet väcks till liv. Det finns en politiskt färgad proveniens, vilket vi anar av slogans med utropstecken, som $\mathrm{i} »$ no cow!». Ytterligare ett exempel är framsidans negerande slogan som förbjöds efter rättegången 2015: »No milk. No soy. No badness.» Negationerna presupponerar en värld som är fördärvad, med »badness», där mjölk och soja är matprodukterna som förstör. Typsnittet är det klassiska Courier, som väcker associationer till 1900talets skrivmaskiner, en tid, kan man tänka, där ord var ord och människor sa som det var. Det kan noteras att Oatly inte förklarar varför alternativ mjölk gjord på soja är dålig. Som vi förstår det är en anledning att sojaproduktion är omdiskuterad eftersom den sker storskaligt, också i regnskogsområden, och till
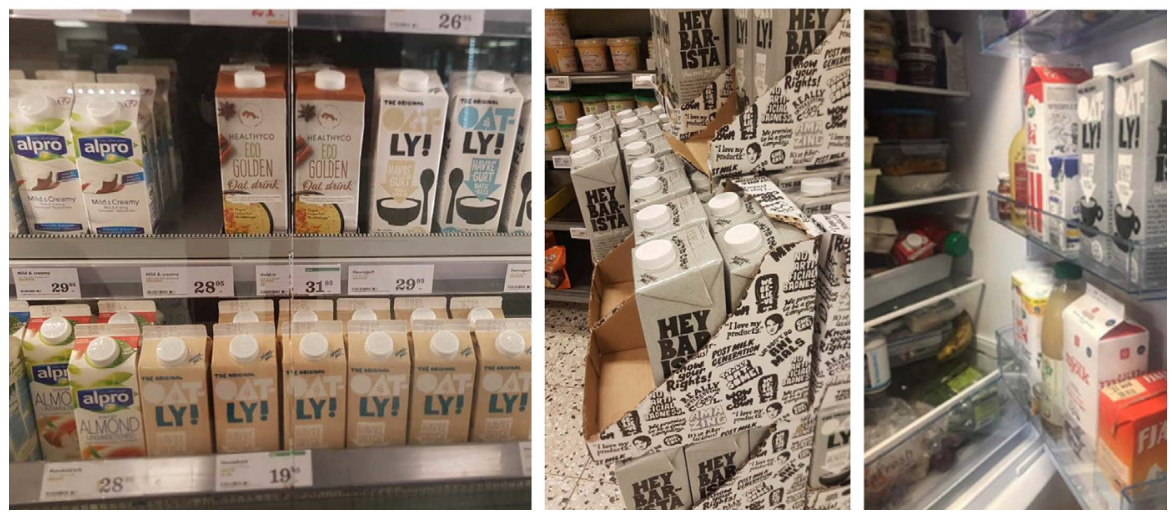

Figur 3. Oatlyförpackningar i kyldisken, på butiksgolvet och i kylskåpet (författarfoton). 


\section{Per Ledin \& David Machin}

övervägande del blir till djurfoder. Ytterligare en anledning är att Oatlys huvudkonkurrenter, amerikanska Alpro och brittiska Silk, traditionellt har sojamjölk som hälsoalternativet.

En annan sorts dåtid iscensätts med populärkulturella referenser. Ser vi på baksidan av förpackningen i figur 2 så möter vi, vilket vi är vana vid och även är reglerat av lag, en ingredienslista, där andelen fett, protein, kolhydrater, vitamin D osv. listas på svenska. Men rubriken är ovanlig och lekfull och på engelska: »THE BORING SIDE», skrivet i ett till synes handmålat typsnitt med droppande färg. Vi kan tänka på den gamla skräckfilmsklichén med något skrivet med blod på en vägg, eller på en väggmålning med rinnande färg i en urban miljö.

Språket är ofta engelska och inte svenska, vilket ligger i linje med de populärkulturella och ofta anglo-amerikanska allusionerna. Man skulle kunna tänka att det vore naturligt att alludera på en oförstörd svensk landsbygd på just svenska för att kommunicera det autentiska och oprocessade. Som vi sett gör Arla det för att kommunicera att mjölk ger en naturlig hälsa (Andersson 2019). Oatly är däremot coola, uppkäftiga och urbana, allt annat än traditionell landsbygd. De har en svensk referens (skriven på engelska) på framsidan, en serietidningsaktig pratbubbla med utropet »it’s Swedish!». På så vis vill de, liksom IKEA, anspela på Sveriges rykte om att vara modernt, jämställt och demokratiskt i den internationella marknadsföringen (jfr Kristoffersson 2015).

Som vi ser i figur 4 varierar Oatly systematiskt sidorna på förpackningarna, något som är typiskt för förpackningsdesign och som Oatly gör på sitt lekfulla sätt. En Oatly-konsument kan med nyfikenhet se fram emot vad nästa associationsrika, roliga och politiskt laddade budskap ska bli, vilket förutsätter att vi kroppsligt tar oss an förpackningen och vänder på den. På den högra förpackningen i figur 4 möter en typisk paradox: »IT TAKES BRAINS TO BE STUPID», där P:et är lekfullt vänt bak och fram (se också pallen med produkter i mitten av figur 3, som pryds av Oatlys många lekfulla typsnitt). Som Bateson (1972) förklarar är det sådana här (skenbara) paradoxer som kräver inramning, att vi förstår metakommunikationen, den position varifrån utsagan yttras. Här ska vi alltså förstå poängen med att på en och samma gång vara smart och korkad, och den får vi om vi läser brödtexten: »We must look extremely dumb sometimes. Little Oatly in the south of Sweden thinking we can help the food industry become more accountable for their actions.» Den inramning som förklarar paradoxen handlar alltså om sanningssägaren, den som med oförstörd blick - vi anar det av det barnsligt-naiva typsnittet - ser på världen och vågar gå emot överheten. 
Figur 4. Sidan på svenska Oatlyförpackningar från 2019 (författarfoto).

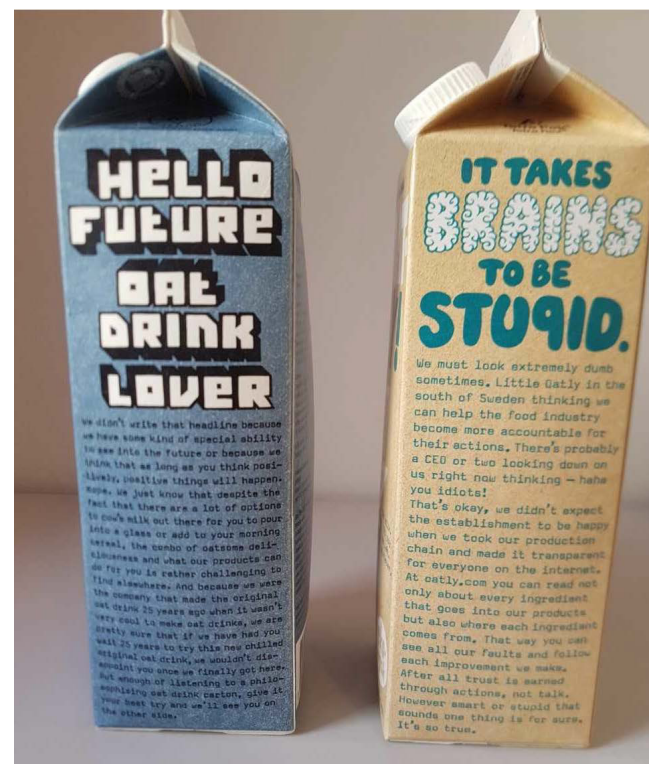

Den grafiska designen stöder denna tolkning, eftersom den frångår traditionella estetiska principer. Förpackningarnas brödtexter saknar marginaler, vilket bryter mot regler om läsbarhet (t.ex. Hellmark 1991). Typsnittet på den vänstra förpackningen i figur 4 tycks efterlikna de lågpixlade och ojämna bokstäver som fanns på tidiga datorskärmar eller datorspel, som Space Invaders på 1980-talet. Bokstäverna är skuggade, vilket ger en tredimensionell effekt, men skuggningen är ojämn och opolerad, som vore det en amatör som gjort den. Om vi studerar den första bokstaven i varje ord framstår skuggningen som slumpmässig, rentav ful. Så Oatly använder grafisk design för att signalera att de går sina egna vägar och struntar i konvenansen.

Som vi sagt är att förkroppsliga rummet typiskt för Oatlys kommunikation. Vi kan ana detta från de varierade förpackningssidorna med oväntade designlösningar. Än tydligare blir förkroppsligandet om vi ser på Oatlys stora affischer, där förpackningar återkommer. I figur 5 ser vi en jätteaffisch som i mars 2019 satt på det gamla posthuset i Helsingfors, mitt i centrum bredvid centralstation (jfr figur 1). De som passerade kunde ofta inte låta bli att vrida huvudet och blicka uppåt. På så vis påverkar den vår perception direkt. Vi möter Oatlys huvudslogan med sin monotona, trokéiska fyrtakt: »It's like milk but made for humans», i sig ett kroppsligt sätt att rytmisera språket, en sorts språklek. Här har vi också det men (»but») som kodar motstridiga förväntningar och polemik. 


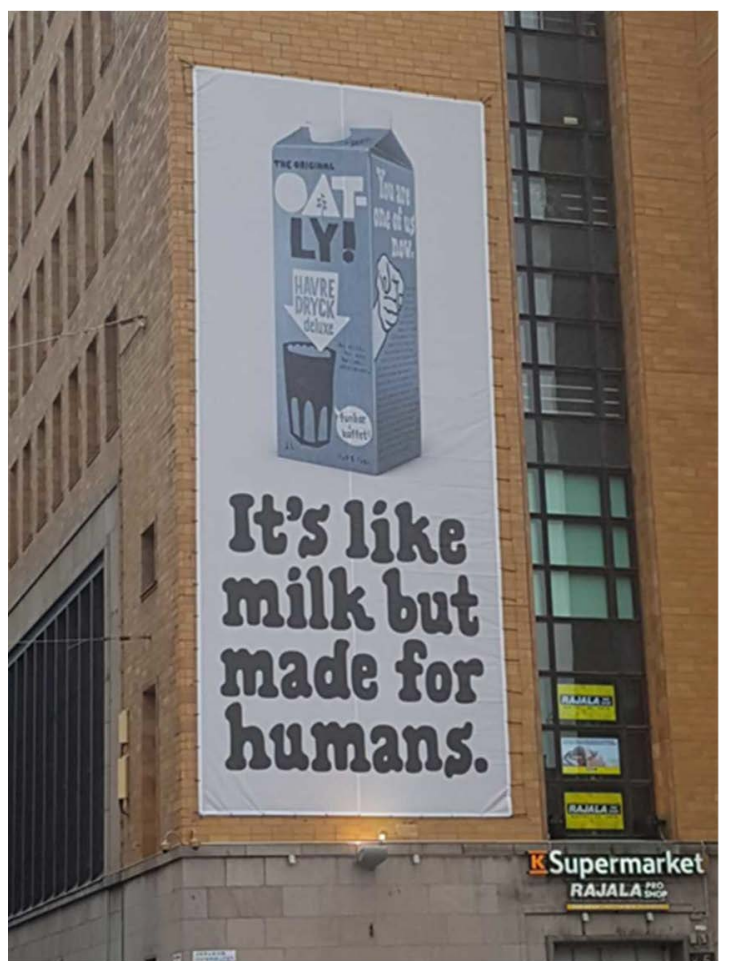

Figur 5. Affisch från Helsingfors, mars 2019 (författarfoto).

Traditionellt tänker vi att mjölk är en matprodukt för människor, men med detta men impliceras att det i själva verket är Oatlys havredryck som är människoföda.

Man kan hävda att själva storleken på affischen fungerar deiktiskt och i sig är ett förkroppsligat tilltal. Den påverkar vår blick och kroppshållning i det fysiska rummet. Till detta bidrar, vilket är typiskt för Oatly, sidan på den avbildade förpackningen. Som vanligt frammanas ett förflutet, här (en imitation av) en rekryteringsaffisch av en typ som känns igen från 1900-talet, där vi uppmanas ansluta till den politiska kampen. Vi möter en deiktisk gest, ett finger som pekar mot vårt ansikte, från en position långt ovanifrån, vilket kodar en uppfordrande social relation. I sloganen sägs »Y You are one of us now», där den sociala relationen blir att betraktaren fogas in i ett kollektiv, ett vi (»us») som med tidsdeixis (»now») infogas i den pågående och situerade läsakten. Naturligtvis har reklamspråk i allmänhet ett personligt tilltal (se t.ex. Pettersson 1974 om framväxten av du-tilltal i annonser på 1960-talet), men hos Oatly blir tilltalet något mycket mer kroppsligt. 


\subsection{Affischer och kampanjer}

En del av Oatlys marknadsföring är affischkampanjer, där olika offentliga platser omvandlas. Ofta används tåg- och tunnelbanestationer, liksom traditionella 1900-talsbyggnader (jfr figur 1 och 5 från Helsingfors). Affischerna, som innehåller en avbildad förpackning (jfr figur 5), är designade för att förkroppsliga rummet och skapar relationer mellan varandra och till förbipasserande. Ett återkommande grepp är att hänga affischer i långa rader, något vi ser i figur 6 från tunnelbanestationen Rozenthaler Platz i Berlin i september 2018 (se Fiedler 2018 om Berlinkampanjen).

Affischerna refererar till varandra och positionerar betraktarens kropp i det aktuella rummet. Det sker genom deiktiska uttryck för rumsrelationer, inte minst det demonstrativa pronomenet this och adverbet too. Den här affischraden börjar med »THIS POSTER» följt av ett »THIS» som pekar ut förpackningen och därmed drycken (längst upp till vänster i figur 6). Sen följer nio affischer i rad (varav vi ser fyra i figuren) som tillägg och backuper: »AND THIS ONE», »A BACKUP ONE TOO».
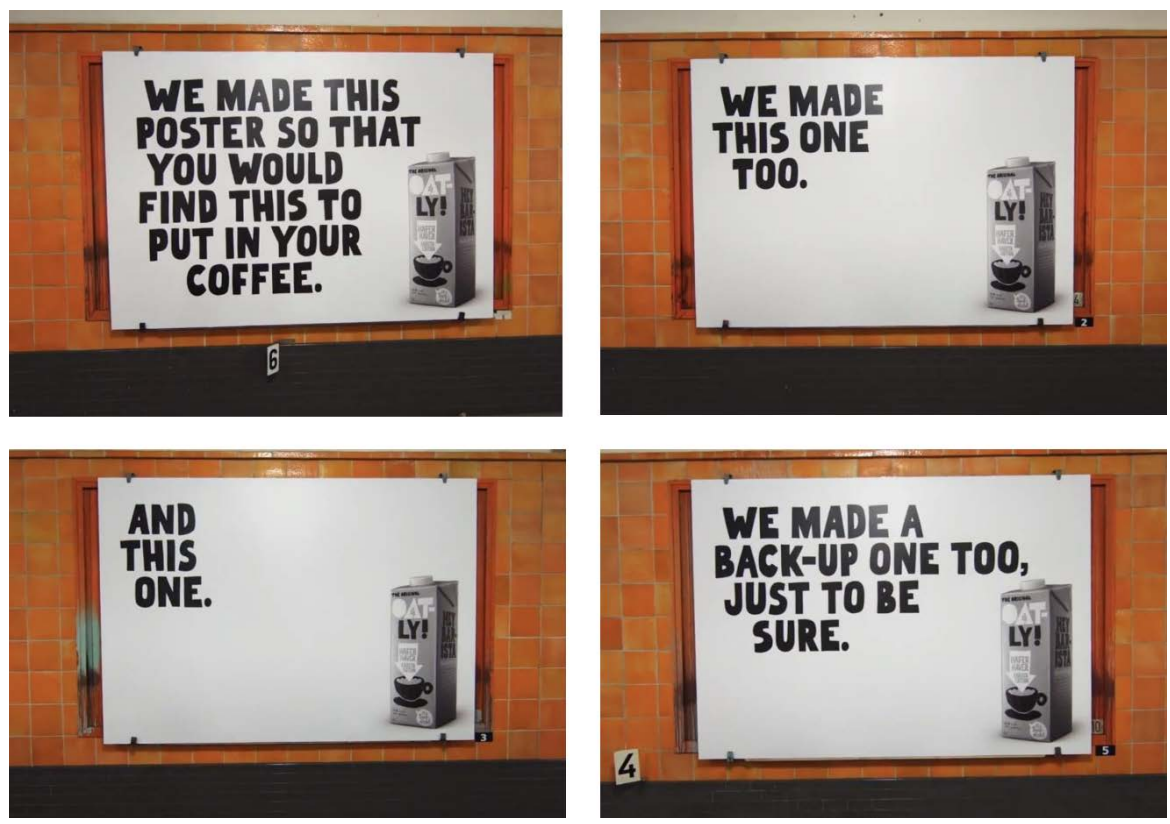

Figur 6. Affischkampanj på tunnelbanestationen Rosenthaler Platz i Berlin, september 2018 (fyra av totalt nio affischer i rad visas i figuren). 


\section{Per Ledin \& David Machin}

Designen är enkel och avskalad. Vi ser de återkommande versala och ojämna blockbokstäverna på en vit bakgrund. Den grafiska utformningen skapar ett intryck av att ett budskap ropas ut med hög röst, samtidigt som ojämnheten visar på något opolerat eller handgjort. Vi kan notera att produktnamnet på förpackningsframsidan står på tyska »HAFER HAVER», följt av specifikationen »BARISTA EDITION», medan sidan, vilken som sagt är viktig på förpackningarna, är på engelska med rubriken och hälsningsfrasen »HEY BARISTA». Det är med andra ord produktnamnet på framsidan som språkanpassas - i Sverige heter det havredryck och i England oat-milk. Det är ingen slump att affischen tar upp barista-drycken, som i många länder lanseras som huvudprodukten och det rätta valet för den som vill njuta en latte (jfr Oatly 2019 om den amerikanska lanseringen och se mittenfotot i figur 3, där en pall med baristadryck, som inte är en kylvara, står på ett svenskt butiksgolv).

Tilltalet är förkroppsligat. De deiktiska uttrycken, i stora versala blockbokstäver, gör att uppmärksamheten flyttas från affisch till affisch, också beroende på kroppens position, om vi står på perrongen eller kommer in till stationen $\mathrm{i}$ ett inbromsande tåg. Vi får en känsla av detta i figur 7 där vi ser ett tåg passera och skymma sikten mot affischraden. Detta ligger i linje med vad Spinoza (1994) säger om affekt, hur kroppens rörelse och position i rummet påverkar perceptionen. Affischraden är ämnad att väcka nyfikenhet och bryta mot våra förväntningar på reklam. Metakommunikationen är besläktad med språklekar, bara att det nu är en fysisk lek, inte helt olik kurragömma på det sättet att affischer dyker upp och försvinner beroende på hur vi och andra rör oss. Raden med återkommande affischer ger en linjär och rumslig rytm att relatera till ut-

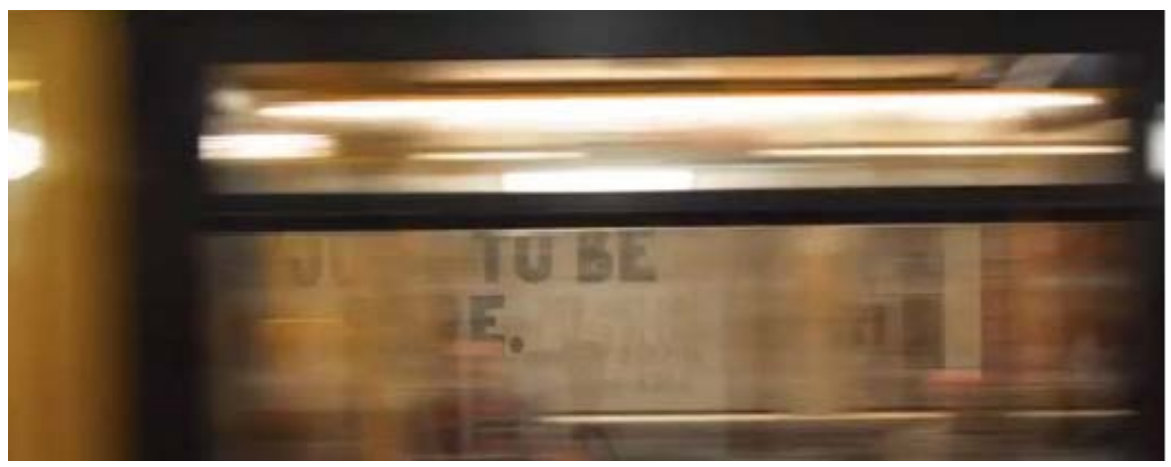

Figur 7. Ett tåg passerar Rosenthalzer Platz och skymmer sikten från perrongen. 
ifrån kroppens fysiska placering och rörelse. Detta är också beroende av det Lefebvre (2004) kallar stadens rytmer, alltså om vi är på väg till eller från jobbet, ska träffa en vän, om vi väntar eller sitter på tunnelbanan eller är på väg ut från stationen i lugn och ro eller i trängsel och rusningstrafik. Uppenbart är att Oatly har en känsla för storstadens rytm och puls i sitt sätt att kommunicera.

I figur 8 ser vi ytterligare en affischrad, nu från Stockholm i januari 2018 och placerad i gången ut från den nybyggda pendeltågsstationen vid Odenplan. Här fungerar nominalfrasen »17 POSTERS» deiktiskt. Den markerar hur affischerna sträcker ut sig och inviterar förbipasserande att utforska dem. Liksom i Berlin kodas den sociala relationen, här med »US» och »YOU». Det direkta tilltalet blir en del av affischernas deiktiska och självrefererande utformning och får sin betydelse i det fysiska rummet. Det är också tydligt att engelska används genomgående när Oatly vill framstå som coola och urbana.

Stockholmsaffischen är paradoxal i att den säger att den inte gör reklam, eller att den inte ger något skäl alls till varför läsaren ska köpa iMAT, som är Oatlys matlagningsgrädde. Som vanligt används en negation i »NO REASON» som gör att Oatly presupponerar en annan, traditionell värld där reklam ger köpskäl, en värld som Oatly säger sig inte vara en del av. Det finns inte heller mycket sakinformation, utan vi får mest veta att affischerna är affischer och hänger bredvid varandra. Paradoxer kräver som sagt inramningar, och den rim-

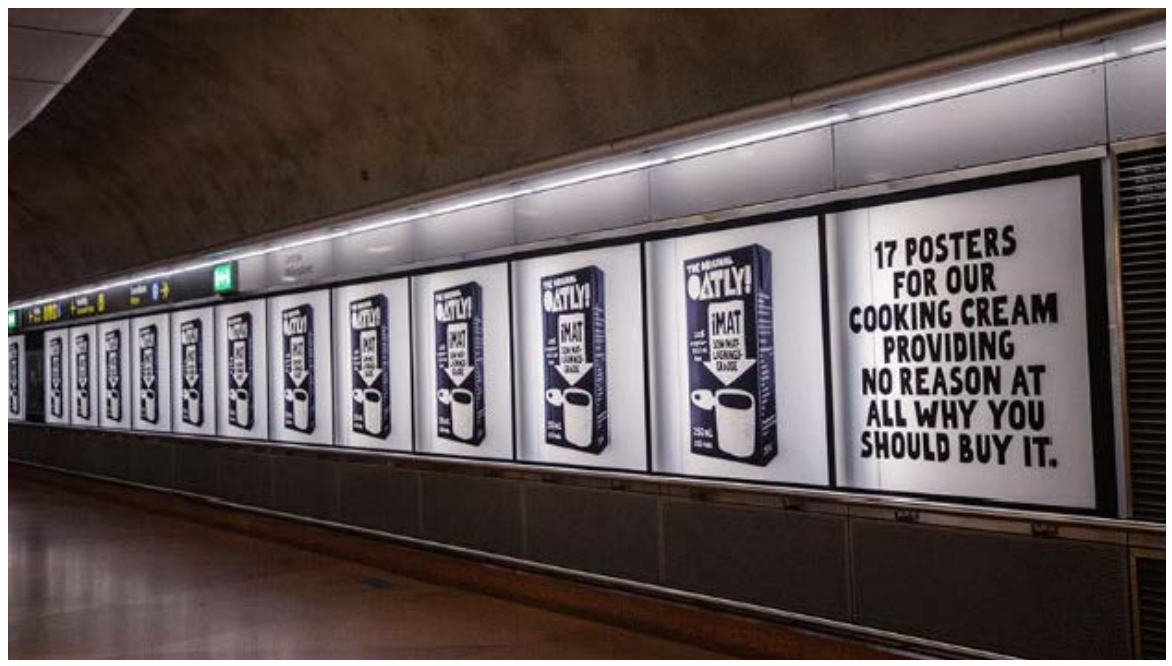

Figur 8. Affischrad från Stockholm, placerad i gången till den nybyggda pendeltågsstationen vid Odenplan, januari 2018. 


\section{Per Ledin \& David Machin}

liga tolkningen är att Oatly gör narr av traditionell produktreklam (för mejerivaror). Det kan tilläggas att Oatlys egen kommunikationsbyrå, som nuförtiden finns in-house, har det självironiska namnet Oatly Department of Mind Control.

Det är inte alla kampanjer som renodlar den här typen av lekfull och självironisk ton. I maj 2019 genomfördes kampanjen »Hey food industry, show us your numbers» i Stockholm (se Törner 2019b). Här uppmuntrar Oatly livsmedelsindustrin att redovisa siffror för klimatpåverkan eller »carbon footprint» som det står på förpackningarna. Oatly har anlitat företaget CarbonCloud att räkna ut s.k. koldioxidekvivalenter. Vi ser sådana siffror på förpackningarna till höger i figur 9, och de är, från vänster till höger, från minst till mest fet havredryck, 0,33, 0,35 och 0,38.

Typsnittet i kampanjsloganen, med åtskilda och kantiga ytor, framkallar som vanligt ett förflutet. Det har en proviens som för tankarna till tidiga digitala produkter, som 1980-talets tv-spel eller de första persondatorerna, eller en film som Matrix från slutet av 1990-talet. De små mellanrummen i typerna ger en likhet med blinkande tecken på en skärm (jfr typsnittet till vänster i figur 4). Det torde vara en association som ligger i linje med Oatlys ambition att utmana livsmedelsjättarna på sifferredovisning.

Återigen utnyttjas det fysiska rummet och offentliga platser strategiskt. Veporna i taket (till vänster) är från Stockholms centralstation, affischtavlan (i mitten) från förorten och Farsta centrum, och stickern (till höger) från bordet $\mathrm{i}$ en tågkupé - jämför det gamla posthuset i Helsingfors i figur 5. När kampanjen tas upp i Resumé 2019 säger pr-chefen: »Vi vill gärna vara en del av det offentliga samtalet och då faller det sig naturligt att vara en del av det offentliga rum-
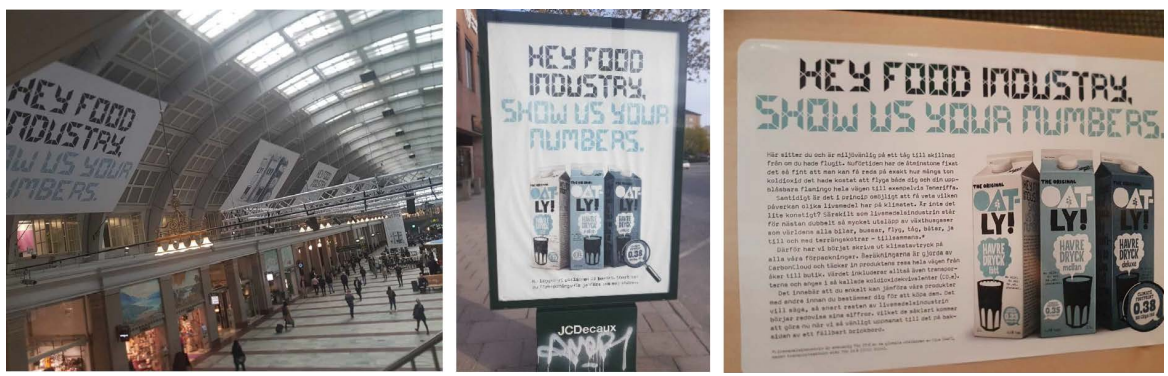

Figur 9. Tre semiotiska material från Stockholmskampanjen Hey food industry: vepor i taket på Stockholms centralstation, en affischtavla från Farsta centrum och en sticker på det utfällbara bordet vid ett tågsäte, maj 2019 (författarfoton). 
met. Därför gör vi ganska mycket reklam där folk rör sig, typ utomhus och på centralstationer.» (Törner 2019b).

Till skillnad från i de andra affischkampanjerna används svenska i denna kampanj, något som förekommer när Oatly lämnar sin lekfulla, uppkäftiga och ironiska stil och vill prata allvar. På affischtavlan från Farsta läser vi längst ner: »Nu lägger vi utsläppen på bordet. Snart kan du förhoppningsvis jämföra dem med andras.» Här har vi återigen det direkta tilltalet (»vi» och »du») tillsammans med tidsdeixis (»Nu» och »snart»), som pekar mot en bättre framtid där alla livsmedel har Oatlys klimatredovisning.

I stickern på det utfällbara brickbordet återfinns, strategiskt nog, en jämförelsevis lång text, som så ofta i 1900-talstypsnittet Courier. Tågpassagerare har mer tid för läsning än folk som skyndar genom stationer. Så här lyder den:

Här sitter du och är miljövänlig på ett tåg till skillnad från om du hade flugit. Nuförtiden har de åtminstone fixat det så fint att man kan få reda på exakt hur många ton koldioxid det kostat att flyga både dig och din uppblåsbara flamingo hela vägen till exempelvis Teneriffa.

Samtidigt är det i princip omöjligt att få veta vilken påverkan olika livsmedel har på klimatet. Är det inte lite konstigt? Särskilt som livsmedelsindustrin står för nästan dubbelt så mycket utsläpp av växthusgaser som världens alla bilar, bussar, flyg, tåg, båtar, ja till och med terrängskotrar - tillsammans.*

Därför har vi börjat skriva ut klimatavtryck på alla våra förpackningar. Beräkningarna är gjorda av CarbonCloud och täcker in produktens hela resa från åker till butik. Värdet inkluderar alltså även transporter och anges i så kallade koldioxidekvivalenter $\left(\mathrm{CO}_{2} \mathrm{e}\right)$.

Det innebär att du enkelt kan jämföra våra produkter med andra innan du bestämmer dig för att köpa dem. Det vill säga, så snart resten av livsmedelsindustrin börjar redovisa sina siffror. Vilket de såklart kommer att göra nu när vi så vänligt uppmanat dem på baksidan av ett fällbart brickbord.

* Livsmedelsindustrin är ansvarig för $25 \%$ av de globala utsläppen av $\mathrm{CO}_{2} \mathrm{e}$ (WWF) medan transportsektorn står för $14 \%$ (IPCC 2014).

Den första satsen iscensätter deiktiskt det förkroppsligade rummet och tilltalet. Vi har rumsdexis (»Här»), tidsdeixis, där presensformen »sitter» kodar en pågående läsakt i tågsätet, och ett direkt tilltal med »du». I övrigt sätter texten upp en polemik genom att jämföra och kontrastera. Tåg jämförs med flyg i det första stycket, och i det andra stycket pekas livsmedelsindustrin ut som en miljöbov, faktiskt den största, eftersom dess utsläpp sägs vida överstiga bil, flyg m.m. I avslutningen säger Oatly att de nu går i bräschen för klimatredovisning och uppmanar resten av livsmedelsindustrin att följa efter "på baksidan av ett fällbart brickbord» - allra sist kommer metakommunikation genom rumslig deixis tillbaka. 
Stilistiskt finns det inslag av ett specialiserat språk med ganska tunga sammansättningar: »livsmedelsindustrin», »växthusgaser», »klimatavtryck», »koldioxidekvivalenter» med facktermen » $\left(\mathrm{CO}_{2} \mathrm{e}\right) »$ tillagd, liksom en nominalisering som »beräkningarna». Asterisken sist i det andra stycket listas efter brödtexten med en hänvisning till rapporten »(IPCC 2014)», vilket signalerar formalitet och vetenskap och samtidigt är ett 1900-talssätt att referera till källor. Detta tekniska språk samsas med en enkel, personlig och stundtals retorisk-lekfull stil. Textens du påstås ta med »din uppblåsbara flamingo» på flygresan. Det ställs en vardaglig och direkt fråga, negerad och retorisk eftersom det givna svaret är ja: »Är det inte lite konstigt?» Den långa hopningen i det andra stycket avslutas med ett emfatiskt »ja»: »världens alla bilar, bussar, flyg, tåg, båtar, ja till och med terrängskotrar». Här är det oväntat och lite av en språklek att avsluta med »terrängskotrar», som knappast är ett fordon med samma spridning och klimatpåverkan som flyg eller bil. Att vi genom våra konsumtionsval kan och ska rädda planeten är tydligt. Läsaren uppmanas »jämföra våra produkter med andra innan du bestämmer dig för att köpa dem». Vad Oatlys siffror mer exakt står för och hur vi som konsumenter ska jämföra olika livsmedelsprodukter är inte självklart. Men Oatly erbjuder, här som annars, trevliga och enkla lösningar på komplexa miljöproblem - det går alltid att göra en insats genom att hälla havredryck i kaffet.

Oatly vore inte Oatly om inte det lekfulla också fick ta plats. I figur 10 ser vi en väggmålning från Södermannagatan i Stockholm. Väggmålningar är ytterligare ett återkommande semiotiskt material i Oatlys kampanjer, placerade strategiskt i kvarter med rötter i 1900-talets stadsliv, i det här fallet den forna och nu gentrifierade arbetarstadsdelen Södermalm. Vi kan jämföra med den väggmålning som Fielder (2018) kommenterar från Berlinkampanjen 2018. Den satt på ett numera övergivet hotell vid floden Spree och var gjord med droppande färg av det slag som typsnittet i figur 2 efterhärmar.

Återigen möter vi lite av en kurragömma-lek, eller ett ordpussel. Typsnittet härmar blinkande tecken på en datorskärm och fungerar perfekt för att blanda bokstäver och siffror så att de ser ganska lika ut. Rummet förkroppsligas på så vis att själva storleken på målningen med nödvändighet påverkar vår perception, vi kan knappast låta bli att titta på den, och vår uppmärksamhet dras då till myllret av tecken. Vi möter en sorts rebus som pockar på ett tolkningsarbete. Efter ett tag ser vi att det från rad 2 till 5 går att läsa ut: HEY FOOD INDUSTRY SHOW US OUR NUMBERS. Så lockas vi in i en språk- och sifferlek, samtidigt som det antagonistiska budskapet, där matindustrin utmanas, är tydligt. 
Figur 10. Väggmålning från Söder i Stockholm, maj 2019 (författarfoto).

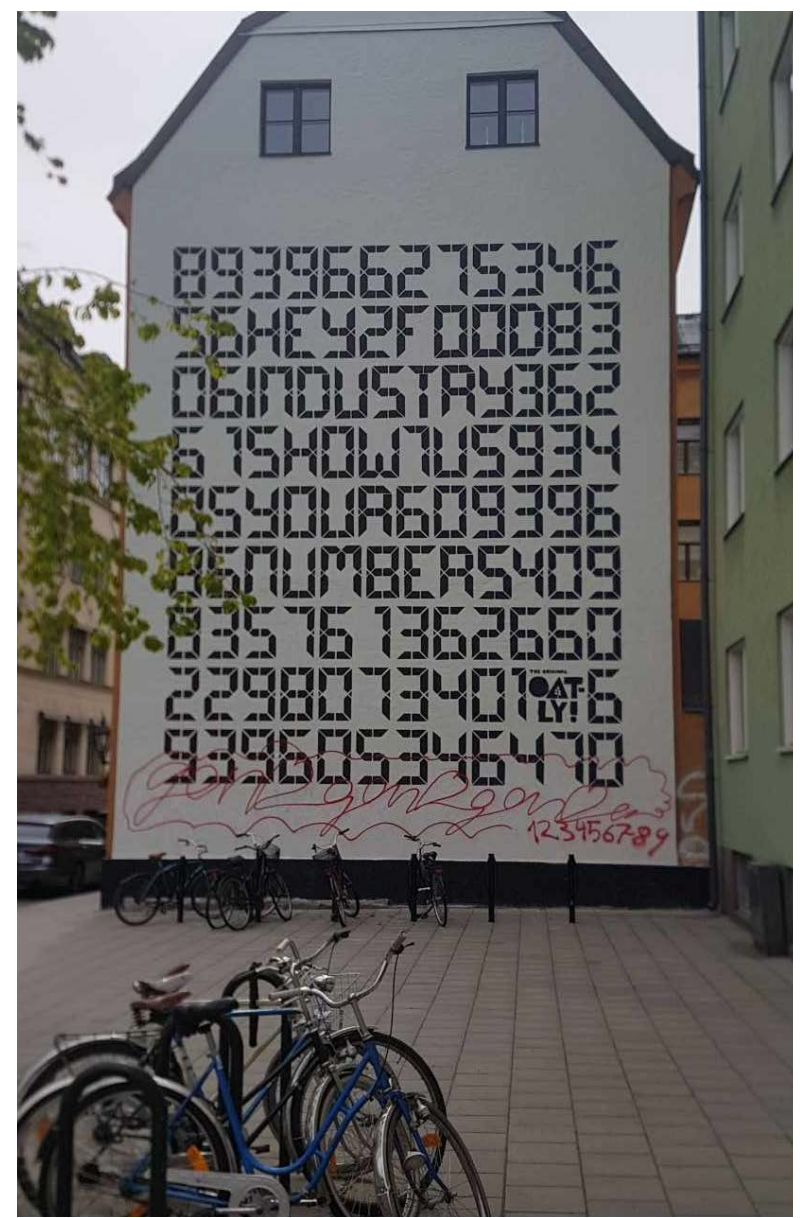

\subsection{Kampanjen Mjölken i skolan och reklamfilmen At school}

Under 2017 drev Oatly kampanjen Mjölken i skolan (se Rågsjö Thorell 2017). Som namnet antyder riktade den sig mot den fria skolmjölk som funnits sedan 1940-talet och särskilt mot det s.k. skolmjölksstödet, som innebär att EU subventionerar olika mjölkprodukter i svensk skola. Oatly ville gå emot mjölk som normen för lunchdryck, lansera havremjölk som alternativet och även påtala mjölkindustrins klimatpåverkan.

Vi ska snart detaljanalysera en reklamfilm men vill först påpeka att kampanjen som vanligt innefattade en rad kanaler och semiotiska material. Viktig och 
återkommande var den s.k. För- och motboken, ett häfte som kunde laddas ner från hemsidan, med undertiteln »Ett diskussionsinlägg om mjölk» - återigen är språket svenska och med inslag av formalitet i sammansättningen »diskussionsinlägg». I övrigt består häftet av 20 sidor där värderande påståenden från mjölkanhängare utgör rubrikerna på varje sida. Dessa går Oatly emot, ofta genom att hänvisa till mjölk- och köttindustrins växthusgasutsläpp. Ett exempel på ett sådant påstående, som Oatly i brödtexten problematiserar och polemiserar mot, är: »Jag har druckit mjölk i hela mitt liv och mår hur bra som helst.» Denna typ av dialogisk argumentation har en lång historia och användes till exempel av organisationen Nej till EU i kampanjen inför folkomröstningen 1994 (Ledin 1994), vilket återigen pekar på hur Oatly frammanar ett förflutet och återanvänder uttryck för politisk protest. Dessutom väcker motbok, som var ett sätt för staten att försöka minska alkoholmissbruket och som avskaffades 1955, 1900-talet till liv. Att kampanjen på så vis möjliggör associationer mellan mjölk och missbruk är förstås ett medvetet grepp av Oatly.

Reklamfilmer var viktiga i denna kampanj och utformades med VD:n Toni Petersson som protagonist och förkämpe för det goda. Den återkommande antagonisten kallas Kohuvudet och står för invanda föreställningar om mjölk och representerar ytterst mjölkindustrin. Miljöerna är enkla och vardagliga och innefattar till exempel ett besök på Oatlys fabrik i Landskrona och (med tydlig udd mot Arla) ett kosläpp. Av de fem klipp som släpptes väljer vi att detaljanalysera den 40 sekunder långa At school (som alltså har en engelsk titel men dialog på svenska), där miljön är en skolgård.

Vi gör en genreanalys och utgår från berättelsestrukturen, som i mycket liknar den enkla underhållande berättelse som ofta används i reklamfilmer (se Ledin \& Machin 2018 kap. 7). Vi har en utgångssituation och en komplikation, som blir det problem som driver handlingen. I den här filmen, och på grund av dess antagonistiska karaktär, får vi, som vi ska visa, ingen riktig upplösning så att världen bringas $\mathrm{i}$ ordning, utan ett resultat blir att den politiska kampen måste fortsätta. Vi kommenterar också, utifrån Young (1982), Oatlys sätt att metakommunicera med tittarna.

Vi disponerar analysen efter stegen i berättelsen, mer exakt utgångssituation, komplikation, resultat och koda. Vi använder skärmdumpar för att illustrera stegen. Bredvid skärmdumparna återfinns den transkriberade dialogen. För att visa att vi har att göra med talspråk använder vi gemener och typsnittet Courier. Huvudsatsavgränsning görs med / och avbrott markeras med -. Utrop och fråga återges skriftspråkslikt med! och ?. 
Orientering (1-10 sekunder)

Toni kör på skolgården. Kohuvudet visar sig.

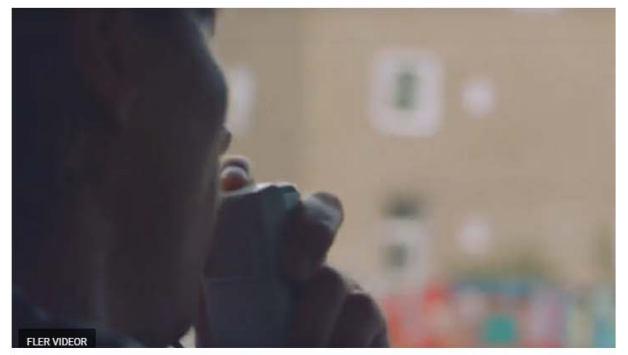

Toni: havre! havre! havredryck!

woah woah woah!

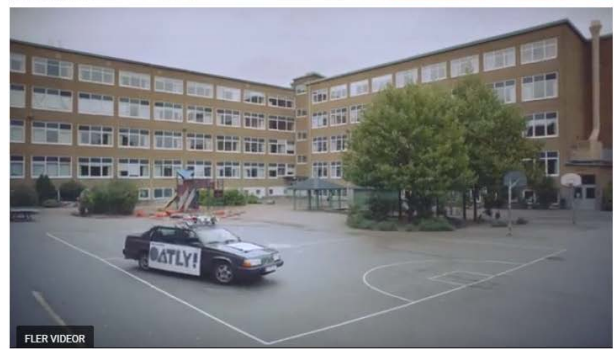

Toni: havre! havre! havredryck!

woah woah woah!

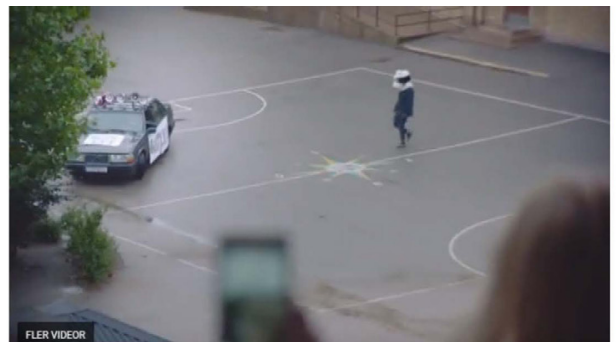

Kohuvudet: toni!

Toni fortsätter att skandera: havredryck! woah woah woah!

Kohuvudet: toni!

Toni fortsätter att skandera: havredryck! woah woah woah!

Miljön är en funktionalistisk skola från 1960-talet med en asfalterad skolgård. Det finns en bollplan markerad men utan mål, och vi ser en rutschkana. Att ett alldagligt, sent 1900-tal framkallas är tydligt också av Tonis gamla Volvo, målad lite som dåtida polisbilar. Vi bjuds in att följa Tonis politiska kamp. Han åker runt och skanderar slagord med »havre» i en mikrofon med en uppsättning megafoner på biltaket. Kohuvudet går mot Toni och försöker påkalla hans uppmärksamhet, vilket Toni inte märker eller vill se. Kohuvudet bär en sorts mjuk maskeradkostym, lite som på ett barnkalas - figuren ser snarare söt än farlig ut. I den nedersta skärmdumpen står ett barn inne i skolan och tittar ner på det som utspelar sig. Som vi ska se är detta en del av en cirkelkomposition. 
Komplikation (11-29 sekunder)

Kohuvudet försöker stoppa Toni från att sprida sitt budskap.

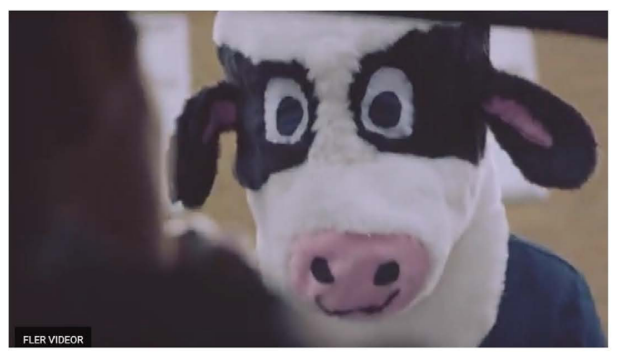

Kohuvudet: toni! stopp stopp!

Toni: vad är det?

Kohuvudet: du kan inte göra reklam pá skolan för din havredryck

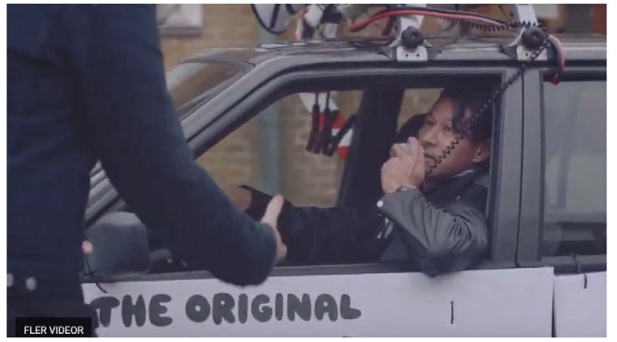

Toni: men EU sätter ju upp affischer för mjölkstödet-

Kohuvudet: -alltsả barn dom

behöver stöd / mjölk är bra / dom behöver näring

Toni: men kan man inte ge stöd åt vegetabiliska drycker också då och inte bara mjök?

Kohuvudet: vad är det för fel med mjölk?

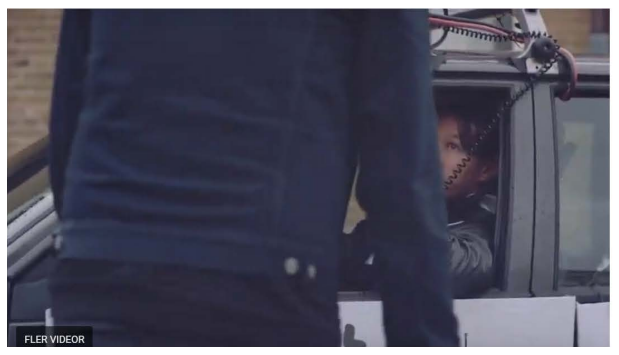

Toni: vad är det för fel med havredryck? det handlar om rättvisa àt barnen / dom ska få välja

Komplikationen inträder när Kohuvudet får kontakt med Toni med uppmaningen »stopp stopp!», följd av ett negerat påstående, modaliserat med hjälpverbet kan, som ger en anmodan: »du kan inte göra reklam på skolan för din havredryck». Toni håller förstås inte med. Det följer en dialogisk argumentation, där Kohuvudet representerar invanda men felaktiga uppfattningar. Barn behöver mjölk och näring, vad är fel på mjölk? Toni invänder hela tiden genom megafonen - med hjälp av men-inledda satser och säger, även om han en gång blir avbruten, att det handlar om EU:s stöd och att även vegetabiliska drycker ska serveras till skollunchen. Kohuvudet tar alltså 
rollen av en sorts ordningsvakt, medan Toni talar från ett retoriskt underläge, som en som vet men inte blir lyssnad på, och, anar vi, också på barnens vägnar.

Röstkvaliteterna och prosodin (som ju inte en transkription får fram) är viktiga för effekten. Kohuvudet talar släpigt och sävligt, och hans kroppshållning och rörelser är också släpiga och slängiga. Prosodin är inte typiskt svensk vad gäller exempelvis stavelselängderna, som framstår som ojämna eller godtyckligt utdragna. Kohuvudet, med sin maskeraddräkt, sin konstiga svenska och sitt försvar för mjölken, är därmed allt annat än genuin. Toni är däremot artikulerad och tydlig, och prosodiskt finns en västsvensk dialekt. Han är alltså ingen överlägsen 08, utan han har en klarsyn som, får vi tro, bottnar i en folklig förankring. Vi anar en man som sätter sig upp mot etablissemanget, mot ett sätt att leva och tänka som han menar är orättfärdigt.

Detta iscensätts med hjälp av fragment av och symboler för politisk kamp. Vi har mött banderoller, megafoner, slogans, typsnitt och ikonografi som för tanken till stenciler och skrivmaskiner och helt säkert till 1900-talets sista decennier. Miljöerna och materialen är genomgående lite slitna, eller ger sken av det. Det finns ett återkommande utanförperspektiv, som gör det möjligt att ta positionen som någon som har sett och förstått och som säger sanningen och utmanar makten. Vi som var unga på 1970-talet kan tänka på vänsterns politiska demonstrationer med megafoner, banderoller och taktfasta slogans.

Som politiska symboler fungerar de här artefakterna även för senare decennier och yngre målgrupper. Den som var aktiv i exempelvis DIY-rörelsen (do it yourself) på 1990-talet känner lätt igen sig. I denna anarkistiska rörelse tog man avstånd från konsumtionssamhället och ordnade och skapade saker själv, utan inblandning av experter och storföretag. Musiken, som förstås låg utanför mainstream, var gärna punk och hardcore. Fanzines skrivna med Courier, liksom megafoner och banderoller, var återkommande artefakter. Vår poäng är att det politiska förflutna som framkallas inte är lokaliserat exakt i tiden och rummet, utan att Oatly medvetet skapar associationer som täcker in olika erfarenheter av politiskt engagemang.

Resultat (30-36 sekunder)

Resultatet blir att Toni fortsätter sitt kampanjande och att Oatly uppmanar till debatt. 


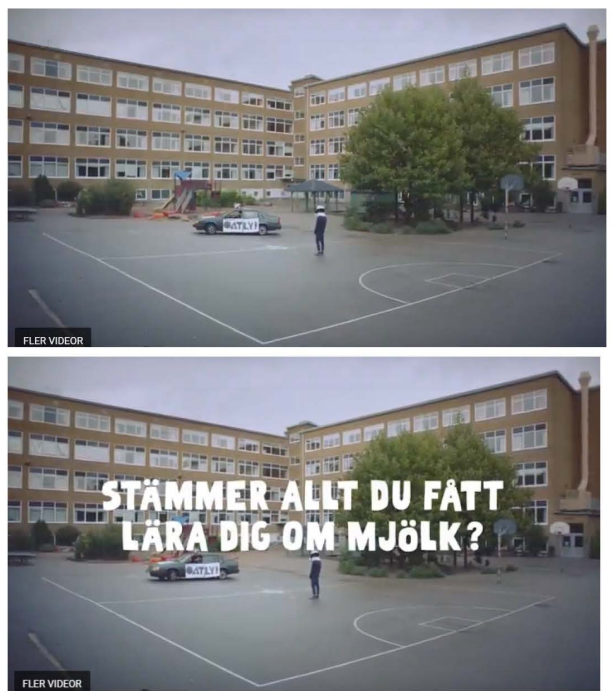

Toni: valfrihet åt barnen! rättvisa åt alla! rättvisa! rättvisa åt barnen!

Toni: rättvisa! rättvisa! rättvisa àt barnen!

Kohuvudet lyckas alltså inte stoppa Toni från att sprida sitt budskap, utan han fortsätter att åka runt och skandera slogans. Det kan noteras att rättvisa, ett begrepp som kan förknippas med vänstern och 1970-talet och andra begrepp som solidaritet, oproblematiskt samsas med det nyliberala begreppet valfrihet, som ju vann mark på 1980- och 1990-talet och hör ihop med kundtänk och privatiseringar: »valfrihet åt barnen! rättvisa åt alla!» En bildtext fälls in med den retoriska frågan: »STÄMMER ALLT DU FÅTT LÄRA DIG OM MJÖLK?». Att den står över skolan gör att det går att läsa in en kritik inte bara av mejerinäringen utan också av det traditionella utbildningssystemet. Kunskaper om mjölk får man inte av skolan, utan av Oatly.

Komplikationen leder därmed till två resultat, som hör hemma i två olika narrativa världar. Sett från karaktärernas värld, som Young (1982) kallar »taleworld», blir resultatet att Toni fortsätter att skandera. Det finns alltså ingen upplösning där allt ställs till rätta, utan kampen måste fortsätta. Det framgår också av att Tonis slogans hörs hela tiden genom resultat och koda. Sett från berättarens värld, som Young kallar »storyrealm» och innefattar den position från vilken karaktärsvärlden kommuniceras, blir resultatet att berättaren, som vi förstår driver Oatlys intressen, vill få till en politisk diskussion. Denna metakommunikation är viktig. Att låta karaktärsvärlden och berättarvärlden mötas på detta sätt gör att poängen med Tonis äventyr blir att bjuda in åskådaren att engagera sig i diskussionen om mjölk och jordens överlevnad (jfr den inbjudan som finns på affischen i figur 5). 
Koda (37-40 sekunder)

För- och motboken visas i bild tillsammans med Oatlys logga.

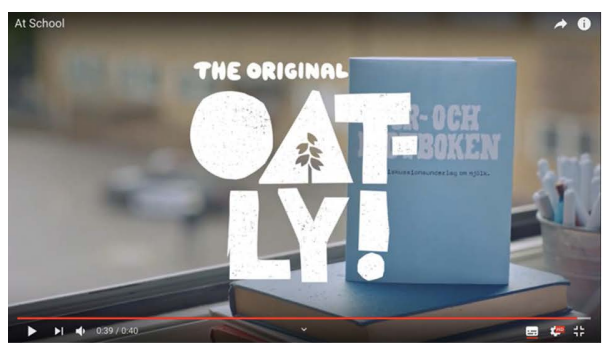

Toni (som fortfarande hörs genom megafonen): havre! havre!

Kameran zoomar ut på samma sätt som den gjorde sist i utgångssituationen och vi ser ner på skolgården från det rum där vi vet att det står barn. Denna cirkelkomposition fungerar narrativt som en snygg avrundning och ideologiskt som ett sätt att ta barnens parti. Vi ser För- och motboken. Namnet är en uppenbar språklek, där »för» och »emot» signalerar politisk debatt. Att vi möter boken inne i ett klassrum gör att den får status av en lärobok av en typ som den traditionella skolan saknar.

När loggan »THE ORIGINAL OATLY!» fälls in avslutas filmen, och vi hamnar i det Young (1982) kallar »realm of conversion», alltså hos faktiska sociala aktörer. Det är återigen en kongenial metakommunikation. Berättelsen kopplas till den värld vi lever i, där vi tillsammans med Oatly ska rädda jorden.

\section{Diskussion}

Historien om Oatly är fascinerande. Den börjar med ett patent på ett enzym som låter vatten blandas med havre. Detta havrevatten görs mjölklikt och ska säljas. Det blir på 1990-talet till en bantningsdryck och sedan ett alternativ till mjölk för laktosintoleranta. Efter millenieskiftet blir det en allmän hälsodryck, också för den som vill ta avstånd från mjölk- och köttindustrin. På 2010-talet får havrevattnet snart sagt magiska krafter. I alla fall blir det den dryck som räddar planeten. Förutsatt att vi köper den.

Vi har visat hur detta går till. Mer exakt har vi frilagt hur deras värderingsbaserade marknadskommunikation ser ut efter omprofileringen 2014, där för- 
packningarna var det semiotiska material som stod i centrum. Den blandar det antagonistiska och det lekfulla och utnyttjar olika semiotiska material på raffinerade sätt, och även det fysiska rummet, som blir ett politiskt och varumärkt rum, men också en plats för lek. Det antagonistiska och lekfulla kodas gärna samtidigt, som i sloganen "wow no cow», med en negation som ger en udd mot mjölkindustrin inbäddad i ett barnsligt rim. Ibland dominerar det lekfulla, som i kampanjer med affischer som refererar till varandra, där vi ska engagera oss i en sorts kurragömmalek. Metakommunikationen som uppstår när Oatly säger sig inte göra reklam skapar samtidigt en antagonism, som går ut på att framställa företaget som underdogen som går emot mjölk- och i den senaste kampanjen hela livsmedelsindustrin. Att Oatly är ett globalt storföretag, där sedan ett par år den kinesiska staten är en av huvudägarna, är inget som kommer fram.

Ett utmärkande drag är att reklamen är språktät. Annars har utvecklingen gått mot att det visuella tar mer och mer utrymme på bekostnad av det verbala, så att en annons mycket väl kan sakna egentlig copy eller brödtext. Detta är tydligt i Korpus (2008) undersökning av språket, eller copyn, i Guldäggsvinnande annonser från 1976 till 2007, där skillnaden mellan start- och slutåret är mycket stor. På samma sätt kan nutida reklamfilm mycket väl sakna dialog (Ledin \& Machin 2018 kap. 7). För Oatly, som vunnit många Guldägg sedan omprofileringen 2014, är språket däremot viktigt för att mana till kamp på ett kul sätt. I slogans och självironiska stycken används engelska, vilket ger en cool och urban touch. När mejerinäringen ska utmanas i längre resonemang används svenska, som i kampanjen Mjölken i skolan.

Hela tiden framkallas ett förflutet, lokaliserat i 1900-talets senare decennier, gärna med hjälp av populärkulturella (serie- och skämttidningar, tidiga datorer osv.) eller politiska (taktfasta slogans, megafoner osv.) allusioner. Proveniensen är bred eller vag i den meningen att den inte går tillbaka på en exakt kontext. Den som varit engagerad i en politisk grupp som går emot etablissemanget känner igen sig, vare sig det var på 1970-, 1980- eller 1990talet. Till saken hör också att Oatlys kampanjer äger rum i storstäder och drar nytta av traditionella offentliga platser: det forna posthuset eller centralstationen i Helsingfors och Stockholm, en tunnelbanestation eller väggen på ett nedlagt hotell i Berlin, en gentrifierad före detta arbetarstadsdel eller ett förortscentrum i Stockholm. Allt detta är traditionella 1900-talsplatser, olika knutpunkter där landet administrerades eller där vanliga människor bodde och arbetade. Viktigt för Oatly är att det rör sig om platser med puls och folk i rörelse. Platserna utnyttjas skickligt för att gå den urbana målgruppen in på livet. 
Så ett bidrag som denna artikel ger är att visa hur Oatlys multimodala kommunikation faktiskt är utformad. Att reklamspråk traditionellt är lekfullt och kan vara ironiskt och framkalla ett förflutet, och att det finns ett direkt tilltal, det vet vi (t.ex. Myers 1994). Men Oatlys sätt att göra detta och samtidigt vara antagonistiska och förkroppsliga det fysiska rummet så att vi binds till de semiotiska materialen menar vi, tillsammans med språktätheten, är det retoriskt utmärkande.

Den sortens kommodifierade aktivism som Oatly står för behöver diskuteras och kritiskt belysas. Den innebär att miljömässiga utmaningar tas om hand av globala storföretag och att politiskt engagemang inte blir att engagera sig i den liberala demokratin utan att köpa rätt värderingar - för det är som sagt värderingar som Oatly säljer. Banet Weiser (2012) uttrycker det som att aktivisten i det nyliberala samhället kan vara vem som helst, så länge som varumärkets värderingar stöder konsumtionsvalen. Och valen får oundvikligen en moralisk halt: »participating in brand cultures feels like participating in an ethical or moral frame» (s. 219). Bauman (2007 s. 11) uttrycker något liknande när han säger att denna konsumtion av värderingar omvandlar traditionella sociala relationer »through the annexation and colonization by consumer markets of the space stretching between human individuals». Vår mellanmänskliga samvaro, hur vi relaterar till varandra, betingas alltså av att du som människa blir vad du köper, så att valet mellan att köpa havredryck eller mjölk blir en fråga om vem som tar strid för det rätta.

Matkonsumtion handlar alltså till stor del om »navigating guilt» (Johnston \& Cairns 2012), att hantera skuldkänslor som följer av att känna en oro och en press att göra det goda och rätta. Att köpa och internalisera ett varumärkes värderingar kan vara en lättnad, säger Banet Weiser (2012 s. 219), ett sätt att känna ett lugn i en värld där klyftorna ökar och jordens framtid är i fara. Här menar vi att Oatly är skickliga på att skapa känslomässiga band till varumärket, att förkroppsliga moraliska värderingar och hållningar i sin kommunikation. Att de lyckats samla aktivister beror nog också på att de får konsumenter att känna sig införstådda, att deras språklekar och självironi får målgruppen att känna sig lite smart när den hänger med.

Det hör till saken att den här typen av »high-value-added-products» (Lagnevik m.fl. 2003) köps av en välbärgad medelklass (Banet Weiser \& Mukherjee 2012), av den rikaste procenten av jordens befolkning. För att ingå i den procenten krävs det i dagsläget en årsinkomst på bortåt 29000 euro, något som en heltidsanställd svensk förskollärare eller lagerarbetare har (Kurt 2019). I många av jordens länder, exempelvis Indien, Bangladesh och Malaysia, har yt- 
terst få det. Det är denna rikaste procent som har resurserna att köpa etisk mat och moral - den största delen av jordens befolkning har fullt upp med att överhuvudtaget skaffa sig en inkomst.

Att jorden är hotad är uppenbart, och vi är, liksom många andra föräldrar, oroliga för våra barns framtid. Unga veganer, och många andra grupper, är också oroliga och rädda för om jorden ska finnas kvar. Att välja att köpa havredryck, som en del av jordens rikaste gör, är i det sammanhanget förståeligt, trots att det knappast löser de globala och miljömässiga utmaningar vi står inför. Oatly gör det möjligt för individer att ta ställning för en hållbar planet, att i alla fall göra något.

Det är något annat som för oss skaver med den kommodiferade aktivism som Oatly exemplifierar. Det har att göra med hur vi känslomässigt som individer binds till varumärkeskulturer i vilka vi investerar pengar för att känna oss trygga (Banet Weiser 2012). Vi lever i dag, säger Illouz (2007), i den emotionella kapitalismens tidevarv. Traditionellt är vi vana att skilja mellan sak och person, förnuft och känsla, privat och offentligt, vare sig det gäller att delta i demokratiska val eller köpa något vi behöver. Men i dag är det ekonomiska, inklusive vår matkonsumtion, och det emotionella, inklusive våra privata och intima band till varandra, sammanflätade. Det är också så Banet Weiser (2012 s. 219) beskriver varumärkeskulturer och de »affective connections» de har: »Brand cultures exceed the products they represent and, through this excess, offer community to individuals that assures affective connection with others as well as with themselves.» Här finns, menar vi, en fara. Om globala storföretag ska styra våra pengar och känslor och bestämma vad som är ett miljöproblem, finns det en risk att vi inte klarar att rädda planeten.

\section{Litteratur}

Aiello, Giorgia \& Dickinson, Greg, 2014: Beyond authenticity: A visual-material analysis of locality in the global redesign of Starbucks Stores. I: Visual Communication 13:3. S. 303-321.

Andersson, Helen, 2019: Recontextualizing Swedish nationalism for commercial purposes: A multimodal analysis of a milk marketing event. I: Critical Discourse Studies 16:5. S. 583-603.

Arla, 2019: Brölk? Trölk? Pjölk? Sölk? Nääe. Bara mjölk smakar mjölk. Tillgänglig på: https://www.arla.se/produkter/mjolk/bara-mjolk-smakar-mjolk/ [hämtad 3.5.2019]. Atkinson, Lucy \& Kim, Yoojung, 2015: "I drink it anyway and I know I shouldn't": Understanding green consumers' positive evaluations of norm-violating non-green pro- 
ducts and misleading green advertising. I: Environmental Communication 9:1. S. 37-57.

Banet Weiser, Sarah, 2012: Authentic TMs: The politics of ambivalence in brand culture. New York \& London: New York University Press.

Banet Weiser, Sarah \& Mukherjee, Roopali, 2012: Introduction: Commodity activism in neoliberal times. I: S. Banet Weiser \& R. Mukherjee (red.): Commodity Activism: Cultural resistance in neoliberal times. New York \& London: New York University Press. S. 1-24.

Barthes, Roland, 1977: Image, music, text. London: Fontana.

Bateson, Gregory, 1972: A theory of play and fantasy. I: Steps to an ecology of mind. New York: Ballantine. S. 67-73.

Bauman, Zygmunt, 2007: Consuming Life. Cambridge: Polity Press.

Bauman, Zygmunt, 2017: Retrotopia. Malden, MA: Polity Press.

Beck, Ulrich \& Beck-Gernsheim, Elisabeth, 2002: Individualization: Institutionalized individualism and its social and political consequences. London: Sage.

Burrows, Jessica, 2013: Visually communicating 'honesty': A semiotic analysis of Dorset Cereals' packaging. University of Leeds. Magisteruppsats. Tillgänglig på: http://media.leeds.ac.uk/files/2013/07/Jessica-Burrows-BACS-2013.pdf [hämtad 23.2.2017].

Cavanaugh, Jillian R. \& Shankar, Shalini, 2014: Producing authenticity in global capitalism: Language, materiality, and value. I: American Anthropologist 116:1. S. 51-64.

Clegg, Stewart R., 2018: Reading Bauman and Retropia. I: Scandinavian Journal of Management 43. S. 354-363.

Cook, Guy, 1992: The discourse of advertising. London \& New York: Routledge.

Cook, Jacklyn, 2011: 'Green capitalism' or environmental justice? A critique of the sustainability discourse. I: Focus 63. S. 45-51.

Djerf, Kristin, 2015: Oatly ny huvudsponsor - nu blir Way Out West mjölkfritt. I: Dagens Media 2.6.2015. Tillgänglig på: https:/www.dagensmedia.se/medier/eventsponsring/oatly-ny-huvudsponsor-nu-blir-way-out-west-mjolkfritt-6088243 [hämtad 5.5.2019].

Fairclough, Norman, 1992: Discourse and social change. Cambridge: Polity Press.

Fiedler, Pascal, 2018: Oatly's marketing strategy-Unveiling the hype! This brand was sold out in New York. Now, it is coming to Berlin. I: Mission.org 12.9.2018. Tillgänglig på: https://medium.com/the-mission/oatlymarketingadcampaigneeae9250c018 [hämtad 9.5.2019].

Franklin-Wallis, Oliver, 2019: White gold - the unstoppable rise of alternative milks. How wellness upstarts spoiled milk's healthy reputation - and built a billion-dollar industry from juicing oats and nuts. I: The Guardian 29.1.2019. Tillgänglig på https: //www.theguardian.com/news/2019/jan/29/white-gold-the-unstoppable-rise-of-alternative-milks-oat-soy-rice-coconut-plant [hämtad 13.3.2019].

Hansen, Anders, 2002: Discourses of nature in advertising. I: Communications 27. S. 499-511.

Hellmark, Christer, 1991: Typografisk handbok. Stockholm: Ordfront.

Hodge, Bob \& Kress, Gunther, 1988: Social Semiotics. Cambridge: Polity Press.

Illouz, Eva, 2007: Cold intimacies: the making of emotional capitalism. Cambridge: Polity Press. 
Jaworski, Adam \& Thurlow, Crispin, 2010: Semiotic Landscapes. London: Continuum. Johnston, Josée \& Cairns, Kate, 2012: Eating for change. I: S. Banet Weiser \& R. Mukherjee (red.): Commodity activism: Cultural resistance in neoliberal times. New York \& London: New York University Press. S. 219-239.

Jönsson, Håkan, 2006: Den svenska mjölkpropagandan. I: Forskning \& Framsteg 3. Tillgänglig på: https://fof.se/tidning/2006/3/den-svenska-mjolkpropagandan [hämtad 9.5.2019].

Knoblauch, Hubert, 2005: Focused ethnography. I: Forum Qualitative Sozialforschung/ Forum Qualitative Social Research 6:3. Art. 44.

Korpus, Einar, 2008: Reklamiska: Guldäggsannonser 1975-2009. Diss. Örebro universitet.

Kress, Gunther \& van Leeuwen, Theo, 2001: Multimodal discourse: The modes and media of contemporary communication. London: Arnold.

Kristoffersson, Sara, 2015: IKEA. En kulturhistoria. Stockholm: Atlantis.

Kurt, Daniel, 2019: Are you in the top one percent of the world? I: Investopedia 9.5.2019 (uppdaterad version av artikeln). Tillgänglig på:

https://www.investopedia.com/articles/personal-finance/050615/are-you-top-onepercent-world.asp [hämtad 9.5.2019].

Lagnevik, Magnus, Sjöholm, Ingegerd, Lareke, Anders \& Östberg, Jacob, 2003: The dynamics of innovation clusters. A study of the food industry. Cheltenham, UK \& Northampton, MA, USA: Edward Elgar.

Lakoff, Robin, 1971: The role of deduction in grammar. I: C. J. Fillmore \& D. T. Langendoen (red.): Studies in linguistic semantics. New York: Hole, Rinehart and Winston. S. 63-70.

Ledin, Per 1994: Språk och makt i EU-debatten. I: Språk och stil NF 4. S. 19-63.

Ledin, Per \& Machin, David, 2018: Doing Visual Analysis. London: Sage.

Ledin, Per \& Machin, David, u.u. 2020: Introduction to Multimodal Analysis. Andra upplagan. London: Bloomsbury.

Lefebvre, Henri, 2004: Rhythmanalysis: Space, time and everyday life. London: Continuum.

Lindsey, Timothy C., 2011: Sustainable principles: Common values for achieving sustainability. I: Journal of Cleaner Production 19. S. 561-565.

Mccrow-Young, Alexandra, 2016: Changing the world through consumption: The contradictions of political engagement in the case of Oatly. Magisteruppsats. Lunds universitet. Tillgänglig på: https://lup.lub.lu.se/student-papers/search/publication/ 8872536 [hämtad 22.2.2017].

Myers, Greg, 1994: Words in ads. London: Arnold.

Oatly, 2009: Nyhetsbrevet Historien om Oatly. Tillgänglig på: http://mb.cision.com/ Public/MigratedWpy/90618/684324/935b9189c4338638.pdf [hämtad 23.3.2019].

Oatly 2019: Barista Edition Oatmilk. Tillgänglig på: https://us.oatly.com/products/ barista-edition-oatmilk [hämtad 4.5.2019].

Otman, Jacquelyn A., 2011: The new rules of green marketing. San Francisco, CA: Berrett-Koehler Pub.

Pettersson, Gertrud, 1974: Reklamsvenska: Studier över varumärkesannonser från 1950- och 1960-talen. Diss. Lunds universitet.

Regeringskansliet, 2016: Strategi för hållbar konsumtion. Tillgänglig på: 
https://www.regeringen.se/artiklar/2016/10/strategi-for-hallbar-konsumtion/ [häm$\operatorname{tad}$ 3.3.2019].

Rolfsdotter-Jansson, Catarina, 2018: Handbok för en hållbar människa: Ta hand om dig själv och planeten samtidigt. Malmö: Roos Tegnér.

Rågsjö Thorell, Andreas, 2017: Oatly tar strid mot skolmjölken. Resumé 5.10.2017. Tillgänglig på: https://www.resume.se/nyheter/artiklar/2017/10/05/oatly-tar-stridmot-skolmjolken2/ [hämtad 13.1.2019].

Scollon, Ron \& Scollon, Suzie Wong, 2003: Discourses in place: Language in the material world. London: Routledge.

Spinoza, Benedict de, 1994: A Spinoza Reader: The Ethics and Other Works, översatt av Edwin M. Curley. Princeton \& Chichester: Princeton University Press.

Törner, Amanda, 2019a: Oatlys nya drag - varumärkeskyddar Arlas »brölk». I: Resumé 18.9.2019. Tillgänglig på: https://www.resume.se/nyheter/artiklar/2019/09/18/oatlys-nya-drag--vill-varumarkeskydda-arlas-brolk/ [hämtad 20.9.2019].

Törner, Amanda, 2019b: Oatly om den hyllade utomhuskampanjen: »Fler förstår att vi inte bara snackar». I: Resumé 29.4.2019. Tillgänglig på: https://www.resume.se/nyheter/artiklar/2019/04/29/oatly-visar-upp-vad-deras-produkter-gor-for-avtryck-paklimatet/ [hämtad 3.5.2019].

van Leeuwen, Theo, 2005: Introduction to social semiotics. London: Routledge.

Voloshinov, Valentin N., 1973: Marxism and the philosophy of language. New York: Seminar Press.

Wisterberg, Erik, 2015: Oatly förlorar mot Svensk Mjölk - tvingas ändra marknadsföringen. I: Dagens Media 19.11.2015. Tillgänglig på: https://www.dagensmedia.se/ marknadsforing/kampanjer/oatly-forlorar-mot-svensk-mjolk-tvingas-andra-marknadsforingen-6234999 [hämtad 8.5.2019].

Young, Katherine, 1982: Edgework: Frame and boundary in the phenomenology of narrative communication. I: Semiotica 21. S. 292-310. 